\title{
Gece Ekonomisinde Emek ve Muğlaklaşan Sınırlar: Kadın Barmenler ve Cinsel Taciz
}

\section{The Labour in the Night Time Economy and Ambiguous Boundaries: Female Bartenders and Sexual Harassment}

\section{Halime ÜNAL REȘITOĞLU* Özge TOKAT**}

Öz: Bu makale neo-liberal politikaların iş gücü yapısı ve niteliğinde yarattığı dönüşümler üzerinden kadın barmenlerin müşterileri tarafından maruz bırakıldıkları cinsel taciz deneyimlerine odaklanmaktadır. Çünkü bu süreçte işin değişen doğası, ağıllıklı olarak hizmetler sektöründe olmakla birlikte tüm sektörlerde kadın çalışanları cinsel tacize karşı savunmasız bırakmaktadır. Artık çalışanların sadece işlerini yapabilecek bilgi ve beceriye sahip olmaları yetmemekte ürünün değerini artırmak için emek sürecine öznellikleri ile de dahil olmaları gerekmektedir. Bundan dolayı iş tanımında olduğu gibi, iş yerinde neyin cinsel taciz olduğu hakkındaki sınırlar da muğlak bir hal almaktadır. Özellikle gece ekonomisi içinde yer alan müşteriler ile yoğun etkileşimi gerekli kılan işlerde cinsellik pasif bir şekilde mekâna girmekte ve çalışanın emeğinin bir uzantısı haline gelmektedir. Ayrıca, gece hayatının kültürel atmosferi istenmeyen cinsel ilgiyi normalleştirerek cinsel tacizi görünmez kılmaktadır. Bu makalenin amacı kadın barmenlerin müşterileri tarafindan cinsel tacize maruz bırakılma deneyimlerine ve nasıl tepki verdiklerine ş̧ı tutmaktır. Bu amaca ulaşmak için bir anlatı çalışması tasarlanmıştır. Ankara'da barda çalışan veya çalışmış olan 7 kadın barmen ile derinlemesine mülakatlar gerçekleştirilmiştir. Bulgular katılımcıların işlerini yaparken sıklıkla cinsel tacize maruz kaldıklarını ortaya çıkarmışıı. Kadın barmenlerin çeşitli stratejiler geliş̧irerek (örneğin, barı fiziksel bir sınır olarak kullanarak, görmezden gelerek, durumu kişiselleştirmemeye çalışarak, hayalî nişanlılar yaratarak ve giyimlerini kısıtlayarak) cinsel tacize karşı bir kalkan oluşturmaya çabaladıkları tespit edilmiştir.

Anahtar sözcükler: Cinsel Taciz, Gece Ekonomisi, Duygusal Emek, Cinselleştirilmiş Emek

Abstract: This article explores the experiences of female bartenders of sexual harassment perpetrated by customers in the context of the new economy. The changing nature of work leaves the workers vulnerable to sexual harassment in the services sectors where women predominantly work. Employees should not only have the knowledge and skills to do their jobs but also have to be involved in the labor process with their subjectivity to increase the value of work. Therefore, the boundaries become ambiguous about what constitutes sexual harassment in the workplace. Particularly, in work that require intensive interaction with customers in the night time economy, sexuality enters the space passively and becomes an extension of the worker's labor. Moreover, the cultural atmosphere of nightlife normalizes unwanted sexual interest and makes sexual harrasment invisible. The aim of this article is to shed light on the ways female bartenders respond to sexual harassment perpetrated by customers. To achieve this goal, we designed a narrative study. Interviews were conducted with 7 female bartenders, currently or recently working in a bar in Ankara. The findings show participants were frequently exposed during their work to sexual harassment. It has been found that women bartenders are trying to form a shield against sexual harassment through developing various strategies (for example, by using the bar as a physical boundary, trying to depersonalize the situation, creating imaginary engagements and restricting clothing).

Keywords: Sexual Harassment, Night Time Economy, Emotional Labour, Sexualized Labour

\footnotetext{
* Prof. Dr., Ankara Yıldırım Beyazıt Üni., İnsan ve Toplum Bilimleri Fak., Sosyoloji Böl., Ankara.

unalhalime@hotmail.com

** Sosyolog, Ankara. ozgetokattt@gmail.com
} 


\section{Giriş}

Kadınların iş gücü pazarına girmelerinin önünde birçok engel olmakla beraber, iş yerinde karşılaşabilecekleri cinsel taciz bu engellerin en önemlileri arasında yer almaktadır, çünkü iş yerleri ne toplumsal cinsiyetten ne de cinsellikten bağımsız değildir (MacKinnon 1979; Acker 1990; Hall 1993). Toplumsal cinsiyet eşitsizliği ve heteronormativite etrafinda temellenen cinsellik toplumsal düzenin doğal parçası olarak kabul edildiği için bu eşitsiz ilişkiler iş yerlerinde de hayat bulmaktadır (Acker 1990). Makro ve mikro ilişkiler tarafından sürekli yaratılan geleneksel toplumsal cinsiyet kodları ve heteroseksüel ilişkiler tecavüz ve cinsel saldırıyı odak alan cinsel taciz söylemini baskın hale getirmektedir. Bu durum kamusal alanda gündelik hayatın içinde sıklıkla karşılaşılan dokunma, bakma, rahatsız etme, sarkıntılık gibi cinsel taciz davranışlarının ise ikinci plana atılmasını sağlayarak istenmeyen heteroseksüel davranışları doğallaştırmakta ve belirli sosyal bağlamlarla ilişkilendirerek normalleştirmektedir (Anderson, Daly \& Rapp 2009; Kavanaugh 2013). Tecavüz gibi suç kapsamına giren cinsel taciz davranışlarının dışındaki diğer davranışlar ise iş yerlerinde sıklıkla görülmektedir. Cinsel taciz "kişinin itibarını zedeleme niyeti ile yapılmış veya sonucunu doğurmuş olan, göz korkutucu, düşmanca, onur kırıcl, küçük düşürücü veya saldırgan bir ortam yaratan, cinsel içerikli istenmeyen sözel, sözel-olmayan veya fiziksel her tür davranış" olarak tanımlanmaktadır (Eurofound 2013 akt. Toker 2016, 3). Bu kapsamda kişiyi rahatsız eden cinsel ilgiye işaret eden uzun süre bakmak, 1srarla çıkma teklif etmek, cinsel içerikli şakalar yapmak, küçümseyici sözlü veya fiziksel eylemlerde bulunmak, dokunmaya çalışmak, iş birliği karşılığ cinsel birlikteliğe zorlamak gibi sözel veya fiziksel davranışlar yer almaktadır (Toker 2016). Ülke bazında verileri ayrıştırmamakla beraber, Eurofound (2017) tarafından yürütülen Altıncı Avrupa Çalışma Koşulları Araştırması raporuna göre, son bir ay içinde çalışanların \%12'si sözel tacize, \%2'si istenmeyen cinsel ilgiye, \%6'sı aşağılayıcı davranışa ve \%4'ü ise tehdide maruz kalmıştır. Sektörel olarak bakıldığında ise cinsel taciz mağdurlarının en fazla servis ve satış elemanları arasında olduğu rapor edilmiştir (Eurofound 2017). Cinsel tacizin bu işlerde yoğunlaşmasının nedenleri arasında bu sektörlerde kadınların yüksek oranlarda çalışması ile sadece işveren-çalışan ilişkisinin ötesinde çalışan-müşteri ilişkisinin de mevcut olmasıdır. Diğer sektörlerin birçoğunda çalışanlar müşteri ile yakın temasa girmek, hatta onları görmek zorunda bile değildir. Fakat destek hatları, mağazalar, oteller, restoranlar, barlar ve bakım evleri gibi iş yerlerinde çalışanlar müşteri veya bakıma muhtaç kişi ile bazen telefon üzerinden bazen de yüz yüze ilgilenmek zorunda kalmaktadır. Örneğin, sağlık sektöründe yapılan çalışmaların sonuçlarına göre hem hemşireler (Kısa \& Dziegielewksi 1996; Gerni 2001; Kısa et al. 2002; Çelik \& Çelik 2007; Aydemir \& Alıc1lar 2009; Erdemir et al. 2011; Bayram \& Dinç 2012) hem de doktorlar (Ulusoy et al. 2011) hasta ve hasta yakınlarının mağduru olmaktadırlar. Erdemir ve diğerlerinin (2011) araştırma bulgularına göre, araştırmaya katılan hemşirelerin yaklaşık \%72'si hastalarının cinsel tacizine uğramışlardır. Taciz davranışları arasında hastanın rahatsız edici şekilde hemşirenin gözüne bakması, hemşirenin hayatı ile ilgili mahrem ve özel sorular sorması, görüşme ve randevu istemesi, hemşireye dokunmak istemesi veya hemşirenin ona dokunmasını istemesi, cinsel tehdit ve küfür etmesi, cinsel içerikli şakalar yapması yer almaktadır. Sağlık elemanlarının yanı sıra satış elemanları da müşterilerin cinsel tacizinin mağduru veya tacizin şahidi olmaktadırlar. Kadın satış elemanları müşterilerin kendilerine veya çalışma arkadaşlarına yönelik istenmeyen cinsel ilgisine işaret eden sözel ve fiziksel davranışlarına yoğun bir şekilde maruz kalmaktadırlar (Şahin et al. 2012). Otel çalışanları tecavüz dahil olmak üzere cinsel tacizin pek çok türünün mağduru olmaktadırlar (Unur \& Şanlı 2018).

Hizmet sektöründe çalışanların cinsel tacize karşı daha savunmasız olmasının nedenleri arasında çalışanlara dair beklentilerin neo-liberal politikalar ile değişmesi yer almaktadır. 
Çalışanların sadece işlerini yapabilecek bilgi ve beceriye sahip olmaları yetmemekte, ürünün değerini artırmak için emek sürecine öznellikleri ile dahil olmaları gerekmektedir. Emek sürecinde çalışanların müşterilere göstermiş olduğu duygusal emeğin bir parçası olan ilgi, müşteri tarafından cinsel ilginin bir işareti olarak okunabilmektedir. Özellikle, gece ekonomisinin içinde yer alan bar ve kulüpler gibi kültürel atmosferin cinsel tacizi görünmez kıldığı ve normalleştirdiği mekânlarda cinsel taciz, emek sürecinin normal bir parçası olarak sunulmaktadır (Hall 1993; Kavanaugh \& Anderson 2009; Kavanaugh 2013). Kadınların bedenlerinin ve cinselliklerinin sinırlandırıldığı ve neyin cinsel taciz, neyin normal heteroseksüel davranış olduğu konusundaki ayrımın giderek muğlaklaştığı bu mekânlarda çalışan kadınların emek sürecine öznelliklerini dahil ederken, muğlaklaşan sınırlar içinde cinsel tacize karşı nasıl tavır takındıklarını keşfetmek bu araştırmanın temel amacıdır. Bu çalışma kendisini ülkemizde yapılan diğer çalışmalardan ayırmaktadır. Bahsedilen çalışmalar kadınların yoğun olarak çalıştığı sektörlerde gerçekleştirilmiştir. Bu çalışma ise gece ekonomisi içinde erkeklerin hem müşteri hem de çal1şan olarak yoğun olduğu ve kadınlar için tehlikeli olduğu vurgulanan mekânlarda çalışan kadın barmenlerin cinsel taciz deneyimlerine 1şık tutmaya çalışmaktadır. Bu mekânlarda geleneksel kadınlık kodları her an sorgulandığı gibi kadınların cinsellikleri de erkeklerin bakışları ile denetim altında tutulmaktadır. Bu amaca ulaşmak için Ankara'da çalışan 7 kadın barmen ile derinlemesine görüşme gerçekleştirilerek bir anlatı çalışması yapılmıştır.

\section{Emek Sürecindeki Dönüşümler ve Cinsel Taciz}

Neo-liberal politikalar sonucunda işin doğası ve istihdam şartları değişmiştir. Bu politikalar, daha önceki dönemlerdeki çalışma, emek, iş yeri ve işçi kavramlarının anlamlarını değiştirerek istikrar ve kuralların hâkim olduğu bir ekonomiyi istikrarsızlığın ve güvencesizliğin hâkim olduğu bir ekonomiye dönüştürmüştür (Beck 2000; Standing 2014). Esnek çalışma biçimlerinin baskın olduğu bu yeni ekonomide çalışanlardan sürekli kendilerini yenilemeleri, kendi kendilerini yönetme ve sorunları çözme becerisine sahip olması beklentisi uzun çalışma saatlerini zorunlu kılmış ve emek sürecinde çalışanları giderek güçsüzleştirmiştir (Standing 2014). Çal1şanlar sadece işlerini yapabilecek bilgi ve beceriye sahip olmanın ötesinde konuşma, tutum, davranış, giyiniş gibi öznelliğini ortaya koyabileceği unsurları kontrol altında tutmayı ve bu öznelliklerini de işin bir parçası haline getirmeyi öğrenerek performanslarını sürekli artırarak iş yerlerinin kazanç elde etmesine katk1 sağlamalıdır (Hochschild 1983; Adkins 1995; Taylor 1997; Wolkowitz 2006). İstihdam şartlarının değişmesi ve çalışma biçimlerindeki farklılaşmalar kadınların ağırlıklı olarak çalıştığı hizmetler sektöründe çalışanları cinsel tacize karşı savunmasız bırakmaktadır. Çünkü müşteri memnuniyetini artırmayı hedefleyen bu sektörde, çalışanlar belirli davranış, tutum ve görünüş kurallarına uygun davranmak zorundadırlar (Taylor 1997; Guerrier \& Adip 2000; Wolkowitz 2006; Warhurst \& Nickson 2009; Bruner \& Dever 2014). İş için gerekli olan bilgi ve beceri dışında çalışanların öznelliklerini de işe uygun hale getirerek işin bir parçası haline getirmesi zorunluluğu hizmet verme sürecinde çalışan ve müşteri arasındaki sınırları muğlak hale getirmektedir. Özellikle, müşteri ile yoğun etkileşim içinde olmak zorunda olan otel çalışanları, satış elemanları veya barda çalışanlar, çalışma esnasında uymaları gereken kurallar ile müşteriden gelen uygunsuz davranışlar arasındaki sınırın nerede başlayıp bittiği konusunda sorun yaşamaktadırlar (Guerrier \& Adip 2000; Warhurst \& Nickson 2009; Bruner \& Dever 2014); çünkü çalışanlardan bu yeni beklenti biçimleri, çalışanın iş esnasında çalışan olarak kendisi ile birey olarak kendisi arasında sınır çizmesini zorlaştırmaktadır. Müşterinin uygunsuz davranışını işin bir parçası olarak mı, yoksa birey olarak kendisine karşı yapılmış bir davranış olarak mı algılamalıdır? Çalışanların güçsüzleştirildiği çalışma biçiminde müşteriden gelen cinsel tacize karşı çalışanlar savunmasız kalmaktadırlar (Guerrier \& Adip 
2000; Wolkowitz 2006; Warhurst \& Nickson 2009). Kadınların yoğun olarak çalıştı̆̆ sektörlerde ve gece işlerinde, kadın çalışanlardan "kadın doğasının gereği” olarak erkek müşterilere karşı daha hassas bir tavır takınmalarının istenmesi, kadınların ikincil konumlarını pekiştirerek onları cinsel tacize karşı savunmasız hale getirmektedir (Coffey et al. 2018).

Neo-liberal politikaların hizmetler sektöründeki emek sürecini nasıl dönüştürdüğünü ve çalışan ve müşteri arasındaki sınırları nasıl muğlaklaştırdığını anlamada Hochschild'in (1983) “duygusal emek" kavramına başvurmak oldukça faydalı olacaktır. Duygusal emek kavramı çalışanların ilişkisel becerilerine gönderme yaparak iş yerinin daha fazla kazanç sağlaması için çalışan ve müşteri arasındaki etkileşimde ücretli çalışmanın bir parçası olarak çalışanın hem kendinin hem de müşterinin duygularını kontrol etmesini zorunlu kılar. Başka bir ifadeyle müşteriye karşı hassasiyet gösterip, ilgi ve sabırla yaklaşarak çalışan hem kendi hem de müşterinin duygularını yönlendirmeyi becerebilmelidir. Bu bağlamda, kadınların evde yaptıkları işlerin uzantısı olarak görülen servis ve satış işleri, kadın doğasının bir yansıması olarak kabul edilir (Hochschild 1983). Satış elemanlarının, hosteslerin, garsonların temel görevi müşterinin ihtiyaçlarını karşılamaktır. Nasıl bir anne aile üyelerinin ihtiyaçlarını "özenle” karşılıyor ise bu işlerde çalışanların da müş̧erilerine aynı duygular ve davranışlar ile yaklaşması gerekmektedir (Creighton 1982; Hochschild 1983; Good \& Cooper 2016). Pozitif, eğlenceli ve müşteriyi havaya sokma yeteneğine sahip olmalıdırlar. Hizmeti en iyi seviyeye çıkarmak için duygularını yönetmeli, yumuşak ve sakin bir tavır ve tutum göstererek uygunsuz durumlarda bile müşteri memnuniyetini öncelemelidirler (Bolton 2004). Uygunsuz davranan veya başa çıkması zor müşteriler söz konusu olduğunda sorunları kendi başına çözme becerisi göstermelidir (Bolton 2004; Good \& Cooper 2016). Aynı zamanda, iktidar ilişkileri içinde bu tür işler güçsüz bir konuma sahiptir. Çalışanlardan müşteriye karşı itaatkar bir tavır içinde olmaları beklenir. Heteronormatif cinsiyet rejiminde nasıl ki kadın evin içinde iktidar sahibi değil ve aile üyelerinin ihtiyaçları kendi ihtiyaçlarından önce gelir ise, servis işlerinde çalışanların da müşteriye göre ikincil konumlarını kabul etmeleri gerekmektedir. Gülümsemeleri ve sıcak davranışları ile müşteriye hizmet etmekten ne kadar zevk aldıklarını göstermelidirler (Hall 1993). Bu beklentilerin en önemli yansıması ise kurulan ilişkiler ve ilişki biçimleri bağlamında çalışan ile müşteri arasındaki sınırların giderek muğlaklaşmasıdır.

Servis ve satış işlerinde kadınların yoğun olarak çalıştığı dikkate alındığında, çalışanın işinin bir parçası olarak müşteriye göstermiş olduğu samimi tavırlar ile cinsel ilginin göstergesi olan samimi tavırların müşteri tarafından birbirine karıştırılması mümkündür (Good \& Cooper 2016). Aradaki bu muğlaklık cinsel taciz ihtimalini kuvvetlendirmektedir; çünkü iş yerleri cinsellikten arındırılmış yerler değil tam tersine kadının cinselliğinin görünmez kılındığ 1 veya işe uygun bir hale getirilerek sunulmasının teşvik edildiği yerlerdir (Spradley \& Mann 1975; Acker 1990; Hall 1993). Servis ve satış gibi müşterilerle yoğun etkileşimin olduğu işlerde, işin kendisi cinselleştirilmiştir (sexualization) (Adkins 1995; Guerrier \& Adip 2000; Kavanaugh 2013). Servis işinde sıklıkla cinsellik pasif bir şekilde mekâna girmekte ve çalışanın emeğinin bir uzantısı haline gelmektedir (Warhurst \& Nickson 2009). Müşteriler çalışanların görünüşleri veya bedenlerini arzu alanı olarak görerek cinselliği çalışan-müşteri ilişkisine taşıyabilmektedirler (Riach \& Wilson 2014). Heteronormativite etrafında örgütlenen iş yerlerinde kadınların feminenlikleri iş ortamını bozan bir tehdit olarak görüldügü için kadınların cinsellikleri sınırlandırılmalı veya işe uygun hale getirilmelidir. İş yerlerinde işe uygun giysi ve görünümle ilgili kuralların olması kadınların cinselliğinin işe uygun hale getirilmesi ile ilgilidir (Hall 1993; Kavanaugh 2013; Riach \& Wilson 2014). Havayollarında çalışan hosteslerin cinsellikleri davranışları ve giysileri aracılığı ile müşterilerin cinsel arzularına hitap edecek bir hale getirilmektedir. Virgin Blue havayolları şirketi bir gazete tarafından dünyanın en seksi havayolları olarak tanımlanmaktadır (Warhurst \& Nickson 2009). Eğlence sektöründe bazı işletmelerin, 
çalışan kadınların omuzlarını gösterecek şekilde giyinmesini şart koşması kadınların cinselliklerini nası1 işin bir parçası haline getirmek zorunda olduğuna işaret etmektedir (Adkin 1995). Çalışanların çoğunluğunun kadın olduğu konaklama hizmetlerinde otel alanı cinselleştirildiği gibi otelin işlevleri de cinselleştirilmiştir. Müşteri evinden uzaktayken bile verilen hizmet sayesinde evinde gibi hissetmelidir. Otel çalışanlarının arkadaşça tavırları onların rolünü cinselleştirmektedir. Otel odaları müşterilerin olası cinsel aktiviteleri gerçekleştirecekleri mekânlardır ve cinsellikle ilişkilendirilmiş odaları satmaktan sorumlu olan "arkadaş canlısı" resepsiyon görevlileri müşterilerin cinsel arzularının nesnesi haline gelmektedirler. Odaları temizlemekten sorumlu olan kadınlar geleneksel oda hizmetçiliği ile özdeşleştirilmekte, müşterilerin cinsel tacizinin nesnesi olabilmektedirler (Guerrier \& Adip 2000).

Barlar ve kulüpler gibi gece ekonomisi içinde yer alan mekânlar cinselleştirilmiş sosyal alanlardır. Çünkü bu alanlarda istenmeyen cinsel ilgi hem yaygın hem de normalleşmiştir. Heteronormatif toplumsal düzenin yansıması olan bu mekânlar erkeklerin " $a v c l$ ", kadınların ise " $a v$ " olduğu sosyal alanlardır. Gece hayatının kültürel atmosferi dokunma, bakma, ısrar etme, elle sarkıntılık yapma gibi cinsel tacizleri görünmez kılmaktadır (Kavanaugh \& Anderson 2009; Kavanaugh 2013). Bar endüstrisinde müşterinin özgün bir deneyim yaşamasında çalışanlar önemli bir role sahip olduğundan (Munoz et al. 2006) bu sektörde iş ve eğlence arasındaki muğlaklık hangi cinsel davranışların kabul edilebilir hangisinin edilemez olduğu konusunda karmaşık bir müzakereye sebep olmaktadır (Guiffre \& Williams 1994). Cinselleştirilmiş servis hizmetlerinde çalışan kadınların, müşterilerden gelen istenmeyen cinsel ilgileri işin bir parçası olarak görüp bunlarla baş etmeye çalışması beklenmektedir (Guiffre \& Williams 1994; Adkins 1995). Erkek müşteriler, masaya sipariş almak için gelen kadın garsonu "işte tatlı geliyor" diye karşıllyorlar ise kadın garsonun bunu "mesleki flört" olarak algılaması gerekmektedir (Hall 1993, 465). Müşterilerin "tatlım", "bebeğim" ifadelerini kullanmaları veya 1slık çalmaları garson olmanın ayrılmaz parçası olarak görülmelidir (Huebner 2008, 80). Kadın barmenlerin veya garsonların sipariş alma, müşterilerle şakalaşma gibi günlük rutinlerini yerine getirirken giymek zorunda oldukları üniformalar ile cinsellikleri işin bir parçası haline getirilir (Spradley \& Mann 1975). Yanık tenli kız imgesini yaratmak zorunda olan Hooters çalışanları, müşterilerin onların bedenlerine hafifçe dokunmalarını işin bir parçası olarak algılamalıdırlar (Guiffre \& Williams 1994). Mesleki flörtleşme ve emeğin parçası haline gelen cinsel performans daha fazla satış yapma ve bahşiş almanın bir yolu olarak görülmektedir (Riach \& Wilson 2014). Fakat kadın çalışanlar çoğunlukla bu flörtleşmeyi işlerinin bir parçası olarak yapıyor olsalar ya da yapmak zorunda kalsalar da müşterinin yaklaşımını bir cinsel taciz olarak değerlendirmektedirler. Böyle durumlarda müşteriye "ses çıkarmadan" işlerine devam etmek zorunda olmaları kendilerini kötü ve güçsüz hissetmeleri ile sonuçlanmaktadır. Müşteri ve kendileri arasındaki iktidar ilişkisi tacizci ile yüzleşmelerinin önündeki bir engel olarak karşılarına çıkmaktadır (Huebner 2008). Çünkü, yüzleştikleri durumda da ya işten çıkarılırlar ya da işten ayrılmak zorunda kalırlar (Guerrier \& Adip 2000).

Gece ekonomisi heteronormatif maskülen değerlerin ve geleneksel toplumsal cinsiyet kodlarının hâkim olduğu bir kültürel atmosfere sahiptir (Kavanaugh 2013; Nicholls 2017). Genç kadınlar için zevk ve tehlikenin iç içe geçtiği bu ekonomide geç saatlerde kadınların ister çalışan ister müşteri olsun, bu tür ortamlarda bulunmalarının riskli olduğu düşünülmektedir (Hubbard 2007). Alkol, cinsellik ve eğlencenin birleştiği riskli ortamlarda çalışmayı veya eğlenmeyi kabul ederek geleneksel kadınlık imgesinin "sınırlarını aşmış oldukları" ve kendilerini tehlikelere karşı savunmasız hale getirdikleri kabul edilmektedir. Bundan dolayı, bu ortamlarda bulunan kadınlar "müsait kadın" olmadıkları mesajını karşı tarafa vermek için yoğun çaba sarf ederler, çünkü bu sosyal alanlarda kadınların geleneksel kadınlık normlarına ne kadar yakın olup 
olmadıkları sürekli denetlenmektedir (Nicholls 2017). Sürekli olarak erkeklerin bakışları ile feminenliklerinin ve aslında aynı zamanda da kadınlıklarının test edildiğinin farkında olan kadınlar erkeklerin istenmeyen cinsel ilgilerine karşı kendilerini korumak ve karşı tarafa "yanlış bir mesaj vermemek" için giyimleri, tarzları, davranışları ile saygın bir kadın imgesi yaratmak zorundadırlar; çünkü cinsel tacize uğrarlarsa "riskli" bir ortamda bulundukları için kendilerinin suçlanacağının da bilincindedirler (Kavanaugh 2013). Bundan dolayı, mağdurken suçlu ilan edilmemek için gece ekonomisinin toplumsal cinsiyet normlarının farkında olan kadınlar, bedensel disiplin pratikleri uygulayarak kadınlıklarını ya vurgulamakta ya da baskılamakta, içinde bulundukları atmosfere göre de cinselliklerini ya görünmez k1lmakta ya da kabul edilebilir hale getirmektedirler (Waitt et al. 2011). Erkeklerden gelebilecek istenmeyen ilginin önüne geçmek için bazen bol ve uzun tişörtler giyip kendilerini görünmez kılarken (Leyshon 2003) bazen de sadece hafif bir dekoltesi olan tişörtle yetinmekte veya seksi görünseler bile "tam dozunda" giyinmekteler ve tek başlarına çalışmamakta veya eğlenmemektedirler (Waitt et al. 2011; Griffing et. al. 2012; Nicholls 2017). Kimileri daha gösterişsiz giyinmeye çalışarak cinsel tacizden kaçınmaya çalışmaktadırlar (Mellgren et al. 2017). Bazı araştırmalar, gece ekonomisinde çalışan kadınların cinsel bir obje olarak görülmekten rahatsız oldukları için müşterilerle fiziksel olarak yakınlaşmak zorunda kaldıklarında göz kontağı kurmaktan çekindiklerini, kollarını kavuşturduklarını ve müşteri ile aralarında belli bir bedensel mesafe koymaya çalıştıklarını göstermektedir (Riach \& Wilson 2014).

Gece ekonomisinde "bıçak sırtında" çalışan kadınlar bir taraftan sektörün onlardan beklediği eğlenceli, ilgili ve sabırlı çalışan imgesini yaratmak zorundayken diğer taraftan toplumsal cinsiyet kodlarına uygun davranışları da sergilemek zorundadırlar. Onlar ne "suratsız soğuk kadın" ne de "kolay kadın" olmalıdırlar. Her iki durumda da heteronormatif düzen tarafından kadınlıkları sorgulanacak ve dışlanmaya veya etiketlenmeye maruz kalacaklardır. Toplumsal cinsiyet hiyerarşisinin sürekli inşa edildiği ve mekânın kültürel atmosferi tarafindan cinsel tacizin normalleştirildiği bu tür mekânlarda çalışan kadın barmenlerin deneyimlerine biraz da olsa 1şık tutmaya çalışmanın emek sürecinin karanlıkta kalan yüzünü anlamaya yardımcı olacağı düşünülmektedir.

\section{Yöntem}

Kadınların konuşmaktan ve maruz kaldıklarında polise rapor etmekten en fazla çekindikleri ve çoğu zaman da kendi kendilerini suçladıkları cinsel taciz konusu, bu çalışma kapsamında nitel araştırma yöntemi kullanılarak anlaşılmaya çalışılmaktadır. Ülkemizde iş yerindeki tacizle ilgili çalışmaların çoğu mobbing olarak tanımlanan psikolojik tacizi kapsamaktadır ve cinsel tacize odaklanan sınırlı sayıda araştırma bulunmaktadır (bk. Kısa et al. 2002; Çelik \& Çelik 2007; Erdemir et al. 2011). Cinsel tacizi konu alan çalışmalar ağıllıklı olarak nicel ölçüm tekniklerini (bk. Kısa et al. 2002; Çelik \& Çelik 2007; Erdemir et al. 2011) kullanmış olsalar da, durumun derinliğini anlamak, barmen kadınların yaşadıkları olumsuz deneyimi nasıl anlamlandırdıklarını keşfetmek, yaptıkları işin doğası ile ilişki kurup kurmadıklarını anlamak, baş etmek için geliştirdikleri stratejilerinin çeşitliliğini yakalamak ve toplumsal bağlam ile kendi deneyimlerini nasıl ilişkilendirdiklerini anlamaya nitel araştırma yöntemi daha fazla olanak tanımaktadır. $\mathrm{Bu}$ araştırma bir anlatı çalışmasıdır; çünkü konunun hassasiyeti, ağırlıklı olarak erkeklerin çalıştığ bir mekânda kadın barmenlerin varlığının sınırlılığı ve bu kadınların deneyimlerinin, kadınların yoğun çalıştığ 1 iş yerlerindeki kadınların deneyimlerinden farklılaşma olasılığının mevcudiyeti barmenlerin deneyimlerini derinlikli anlamayı gerekli kılmaktadır (Mishler 1986). Bu araştırmada kadınların dilinden müşterinin istenmeyen cinsel ilgisini anlama çabası içindeyiz. Daha önce tanımlandığı gibi bu araştırma kapsamında istenmeyen cinsel ilgi, tecavüz ve cinsel saldırı 
ile beraber dokunma, sarkıntılık, rahatsız edici bakışlar, sürtünme, sözlü şakalar gibi mekânın kültürel atmosferi ile ilişkilendirilerek toplumsal söylem tarafından ikincilleştirilen ve normalleştirilen davranışları da içermektedir. Bu çalışma, kendisini hem emek sürecindeki son dönüşümleri dikkate alarak önceki araştırmalardan ayırmakta, hem de iş yerinin toplumsal cinsiyet ve cinsellikten arınmış olmadığı tartışmasına odaklanarak sosyolojik bir bakış açısı ile konuyu ele almaktadır.

Bu çalışmada Ankara'da çalışan kadın barmenler ile derinlemesine mülakatlar gerçekleştirilmiştir. Ankara'nın araştırma alanı olarak seçilmesinin nedenleri arasında farklı eğlence kültürlerinin burada yaygın olması gelmektedir. Şehrin farklı semtlerinde öğrencilerin sıklıkla uğradığı barların sayısının yüksek olduğu, farklı semtlerde çoğunlukla mahalle sakinlerinin gittiği mahalle barları olarak tanımlanan mekânların bulunduğu ve gelir seviyesinin yüksek olduğu semtlerde de heterojen bir müşteri grubuna sahip olan barların sayısının az olmadığ gözlemlenmiştir. Daha önceki çalışmalarda olduğu gibi (Bruner \& Dever 2014; Good \& Cooper 2016; Coffey et al. 2018); evrenin tanımlanmasının zor olduğu cinsel taciz gibi hassas bir konuda katılımcıları belirlemek için en uygun örneklem tekniği olan kartopu örneklemi kullanılmıştır (Neuman 2013). Kadın barmenlerin en az bir yıldır barda çalışıyor olmaları şartı temel alınmıştır. Öncelikle başlangıç noktası olarak öğrencilerin yoğun olarak gittiği bir barda kadın barmenin çalıştığı bilgisine ulaşılmıştır. Kadın barmenin çalıştığı bu mekâna gidilerek birkaç saat zaman geçirildikten sonra, katılımcıya araştırmanın amacı açıklanmış ve derinlemesine mülakat için başka bir güne randevu alınmıştır. Randevu günü mülakat gerçekleştirilmiştir. Mülakat sonunda katılımcıdan başka kadın barmen(ler)e yönlendirme yapmasının mümkün olup olmadığı sorulduğunda olumlu yanıt alınmıştır ve diğer mekânda çalışan katılımcıya ulaşılmıştır. Her bir katılımcı bir veya iki diğer katılımcıya yönlendirmiştir fakat yönlendirilen kadın barmenlerin bazıları mülakatı kabul etmemiştir. Bu bağlantı ağı sayesinde yaşları 22-29 arasında olan 7 kadın barmene ulaşılarak araştırma sonlandırılmıştır. Mülakatlar, kadın barmenlerin çalışma saatleri dışında uygun gördükleri zaman diliminde çalıştıkları mekânlarda gerçekleştirilmiştir. Kartopu örneklemi kullanıldığ 1 için örneklemin Ankara gece ekonomisi içinde yer alan kadın barmenleri temsil etmediği akıldan çıkarılmamalıdır. Bulgular katılımcıların kendi iş yerlerindeki deneyimleri ile sınırlı olup bu sektördeki diğer çalışanların deneyimlerini temsil etmemektedir.

Mülakata başlamadan önce katılımcılara araştırmanın amacı anlatılmış ve katılımın gönüllük esasına bağlı olduğu vurgulanmıştır. Mülakatın gizli kalacağı, araştırmanın bulguları değerlendirilirken isimlerinin değiştirilerek onlara takma ad verileceği, çalıştıkları barlarla ilgili ayrıntıya yer verilmeyeceği ve sesli kaydın yazılı metne dönüştürüldükten sonra silineceği söylenmiştir. Katılımcıların onayı alındıktan sonra mülakat gerçekleştirilmiştir. Mülakat iş yaşamındaki zorluklar, çalışma arkadaşları ile ilişkiler, işverenlerin onlardan beklentileri ve müşteriler ile olan ilişkileri etrafında gerçekleştirilmiştir. Katılımcılara deneyimlerini aktarırken en az şekilde müdahale edilmiş fakat gerek duyulduğunda sorular ile ayrıntılara ulaşılmaya çalışılmıştır. Bu çalışma kapsamında ağırlıklı olarak müşteriler ile olan ilişkiler incelenmektedir. Katılımcılar 22-29 yaş aralığındadır ve üniversite mezunu veya öğrenci olanlar mevcuttur. En az bir yıl en fazla 8 yıldır barmen olarak çalışmaktadırlar.

Mülakatlar sırasında alınan ses kayıtları bilgisayar ortamında yazılı olarak çözümlenmiş ve sonrasında kayıtlar silinmiştir. Mülakat metinleri her iki araştırmacı tarafından birkaç kez okunduktan sonra katılımcıların anlatıları arasındaki ortak temaları belirlemek ve inşa etmek için sürekli karşılaştırmalar yapılmıştır. Karşılaştırmalar sonucunda en belirgin olan temalar tespit edilmiştir. 


\section{Bulgular}

Bu kısımda öncelikli olarak kadın barmenlerin çalıșma koşullarına yer verilecek daha sonra cinsel tacizle ilgili bulgular değerlendirilecektir. Kadın barmenlerin çalışma şartlarının derinlikli bir şekilde anlaşılması, katılımcıların cinsel tacize karşı gösterdikleri tepkiler ile ilişkili olduğundan çalışma ortamının analizi oldukça önemlidir.

\section{Çalışma Şartları ve Sosyal İlişkilere Etkisi}

Örgütlenme düzeyi düşük olan eğlence sektöründe ücretler düşük ve çalışma saatleri uzundur. Bensu (29) günde ortalama 8 saat çalışmanın bu sektörde ender bulunan bir durum olduğunu şu şekilde ifade etmektedir: "birçok yerde çalışma saatleri ölümcüldür onu biliyorum genelde 12 saat olur". "Ölümcül” ifadesi şartların zorluğunu oldukça iyi tanımlamaktadır. Benzer şekilde, Buğçe (22) iş çıkış saati olarak gece 02:00'da çıktığı zaman kendisini ölmüş olarak tanımlıyor. Eğlence sektöründe genel olarak ücret düzeyleri düşük olmakla beraber katılımcıların çoğunluğu kendi ücretlerini tatminkâr bulduklarını ifade etmişlerdir. Gündelik ücret alan tek bir katılımcı mevcutken diğer katılımcılar aylık ücret almaktadır ve bahşişler ile beraber ücretleri tatminkâr hale gelmektedir. Katılımcıların bazıları üniversite eğitimlerine devam ettiklerinden, çalışma saatleri uzun olsa bile eğitimleri ve işi beraber götürmek için barmenliği tercih etmektedirler. Bunun yanında gündüz işlerine göre ücretin daha tatminkâr olması da tercihte etkilidir. Amaç, maddi zorluk yaşamadan üniversite eğitimini bitirmek ve mezun olduktan sonra bu işi bırakmaktır. Şu anda çalışmak zorunda olan Aslı (26) barmenlik mesleğine saygı duyduğu halde yaşadığı birçok olaydan sonra mühendis olduğu gün bu işi bırakıp kendi mesleğini yapmaya başlamayı planlamaktadır.

Üniversite eğitimlerini bitirdikleri halde eğitimini aldıkları mesleklerinin çalışma şartlarını zor bulan ve mesleği kendilerine uygun bulmayan bazı katılımcılar, benzer bir ücreti sabah erken kalkmak zorunda olmadan ve zorluklarla karşılaş1lsa bile kendilerini mesleki olarak daha iyi ifade ettiklerini düşündükleri barmenliği tercih etmektedirler. Katılımcıların çoğunluğu yakın zamanda işi bırakmayı planlamıyor olsa bile barmenlikten emekli olmayı da hayal etmemektedirler. Diğer işlerdeki ücretlerin düşük olması ve buradaki kazançlarının daha tatminkâr olmasından dolayı aslında çalışmaya devam etmek zorunda olduklarını ifade etmişlerdir. Örneğin, Deniz (27) bir çıkış yolu arıyor ama bir firsat yakalayamadığı sürece çalışmaya devam etmek zorunda. İşin fiziksel zorluğunun ötesinde psikolojik olarak müşterilerden, patronundan, çalışma arkadaşlarından yorulmuş ve her şey ona ağır gelmeye başlamış olsa bile ücretin görece yüksekliği onu çalışmaya mecbur kılıyor. Özellikle, 30'lu yaşlardan sonra müşterilerin “kahrını çekmenin” giderek zorlaşacağını ve çalışma şartlarına ayak uydurmanın da fiziksel olarak güçleşeceğine inanmaktadırlar. Bir ara bırakıp kısa süreliğine gündüz işlerinde çalışmayı deneyen iki katılımcı tekrar hem maddi nedenler ile hem de gece çalışmaya alıştıkları için barmenliğe geri döndüklerini belirtmişlerdir.

Barmenlikten emekli olma hayalini kurmamanın nedenlerinden birisi de toplumsal baskıdır. Bensu (26) iç mimarlığın çalışma şartlarını zor bulup benzer düzeyde ücret alabileceği bar işine severek girmiş ve hâlâ bu işi severek yapıyor olsa da 30'lu yaşlarına geldiğinde barmen olarak niçin çalışmaya devam ettiğini sorgulayabileceğinin altındaki nedeni, kadın bir barmen olarak çalışmanın getirdiği toplumsal baskıya bağlamaktadır.

Gece ekonomisinde çalışma saatlerinin atipik olması çalışanların sosyal olarak işin dışında etkileşime girme imkânlarını sınırlamaktadır. Gece geç saatlere kadar çalışıp günün çoğunda uyuyor olmak onları sosyal ağlardan uzaklaştırmaktadır. Arkadaşlık ilişkileri çalışma saatlerinin farklılığından dolayı zedelenmektedir ve daha çok arkadaşları, bar çalışanları veya bar müş- 
terilerinden oluşmaya başlamaktadır. 17 yaşından beri barmenlik yapan ve ailesinden ayrı yaşayan Buğçe (22) çalışmaya başlamadan önceki arkadaş grubu ile çalışmaya başladıktan sonraki arkadaş grubunun birbirinden çok farklı olduğunu ve bunun da atipik saatlerde çalışmanın bir sonucu olduğunu ifade ediyor. "Günün 12 saati bazen 15 saati iştesin ve tüm ailen ve arkadaşların bar ve bardaki insanlar oluyo yakın arkadaş çevren onlar oluyo. Bi tane kütüphanede çalışan... Bi avukat bi ögretmen arkadaşım yok benim” (Buğçe, 22). İş ve eğitimini bir arada götürmekte zorluk çeken İlke (22) çalıştığı dönemde, derslere gidememekten yakındığ gibi onu görmek için bara gelen arkadaşları ile sohbet etmenin bile imkânsız olduğundan bahsediyor. Siparişleri yetiştirmek arkadaşlarla sohbet etmekten önce gelir. Bu sefer de arkadaşlık ilişkileri zedeleniyor: "Çalıştığım dönemde ne bulunduğum izci topluluğuna katıllyordum ne arkadaş... Hiç bir şey kalmamıştı ve çalışmayı çok istediğim şey için bir sürü şeyden vazgeçtiğimi fark ettim.... Benim için çok yorucu çalışma saatleri vardl. Her yerim ağrlyarak eve geliyodum ve öyleyken sabah kalkip okula gidemiyodum halim de olmuyodu" (İlke, 22). Her ne kadar aldıkları ücretleri tatminkâr bulsalar da çalışma saatlerinin uzunluğu, hafta sonları müşteri yoğunluğundan sipariş yetiştirirken "arı gibi çalışmak zorunda kalmaları, yarasa gibi gündüz uyup gece geç saatlere kadar çalışmaları" onları ilişki ağlarından uzak tutuyor. Hatta arkadaşlık ilişkileri dışında romantik ilişki kurmak veya var olan ilişkiyi sürdürmek de güçleşiyor. Sevgili ile bar dışındaki ortamlarda buluşmak kendi başına ayrı planlama ve hesaplamayı da beraberinde getiriyor.

\section{Tacizin Kapsamı ve Tacizci Tanımı}

Kadın katılımcıların taciz olarak değerlendirdikleri müşterilerin istenmeyen cinsel ilgisini gösteren davranışlar geniş bir yelpazede yer almaktadır. Müşteriler içki servisi sırasında cinsel taciz içerikli sözel veya davranışsal eylemlerde bulunuyorlar. Müşteriler iltifat adı altında laf atıyor, şiirler yazıyor, peçetelere veya adisyonlara numaralarını yazıyor, sürekli çıkma teklif ediyor, rahatsız edecek şekilde uzun süre bakıyor, dokunmaya çalışıyor veya sosyal medyadan rahatsız ediyor. Bir dönem saçlarını Afrika örgüsü yaptıran Deniz (27) bir müşterinin sürekli saçlarına dokunmaya çalışmasından oldukça rahatsız olmuştur. Katılımcılar için taciz barın sınırları içinde bitmiyor, tam tersine barın sınırlarını aşan hatta özel alana kadar taşan tacizler ile mücadele etmek zorunda kalıyorlar. İnsanların eşleriyle geldiği oldukça küçük bir yerde uzun süredir çalıştığını belirten Aslı (26) bardan beş bina mesafede oturduğu halde o mesafeyi yürürken çoğu zaman korkuyor; çünkü sıklıkla onun işten çıkmasını bekleyen bir müşteri ile karş1laşıyor. Taciz olayı sokakta da bitmiyor, sosyal medya aracılığ (26), başka bir müşterinin sosyal medya üzerinden sürekli onu dürtmesine, ekleyip silmesine ve mesajlarına katlanmak zorunda kalıyor. Benzer şekilde bir defasında Deniz (27) bir müşterinin Eryaman'a kadar takibine maruz kalıyor.

Katılımcıların ifadelerinin işaret ettiği gibi kadın barmenlerin bedenleri, müşteriler tarafından cinsel bir arzu nesnesi haline getirilmiş durumdadır. Servis sırasında bedene dokunmak veya bir bakış atmak için fırsatlar değerlendiriliyor. Sosyal medya aracılığı ile kadın barmenin cinsel bir obje olarak tanımlanması devam ediyor.

Eğlence sektöründe maaşların yanı sıra alınan bahşişler gelirin tatminkâr olup olmamasını belirleyen unsurlardan bir tanesidir. Servis işlerinin iktidar ilişkisinde ikincil konumda olması çalışanların güçsüzleşmesi ile sonuçlanırken ekonomik bağlamda dezavantajlı konumda olan çalışanların geçinebilmek için gerek duydukları bahşiş gibi ekstra gelirler cinsel tacizin aracı haline dönüşüyor. Toplumsal cinsiyet hiyerarşisindeki iktidarını iş gücü pazarındaki ekonomik gücü elinde tutarak pekiştiren erkek müşteri, ataerkil sistemin ona verdiği güç ile kadın barmenleri kendilerinin “özel oda hizmetçileri” olarak görme haklarını kendilerinde buluyorlar. Yüksek 
bahşişler ile hem erkekler iktidarlarını pekiştiriyorlar hem de kadın çalışanları para ile satın alınabilecek nesnelere dönüştürüyorlar. Katılımcılar yüksek bahşişleri taciz olarak algılıyor olsalar bile ekonomik bağlamda güçsüz olmaları tacizci ile yüzleşmelerini engelliyor.

"Bi adam gelmişti tek başına içkisini içiyordu ama bana laf atamıyordu... Saatlerce oturup arada baklyordu sonra hesabi ödemeye gelirken hizmetiniz çok güzeldi çok sağolun diyip bana 100 TL tip atıyodu. Yani değişik anladın mi.. Yani ben o 100 TL tipi görünce sana mi sulanacam" (İlke, 22).

Bazen taciz, sevgi veya sevda adı altında kadın barmenlerin karşısına çıkmaktadır. Erkekler yardımsever görünerek, kadınlara gösterdikleri ilginin temiz ve iyi niyetli olduğunu belirterek, onları koruma ve kollama niyetinde olduklarını göstererek kadın barmenleri uzun süreli taciz etmektedirler. Hatta niyetlerinin ne kadar ciddi olduğunu "sapık tacizci" bir erkek olmadığını kanıtlamak, saf temiz duygulara sahip olduğunu göstermek için aile üyelerinden birkaç tanesini bara getirip katılımcıya aşkını kabul etmesi için baskı yapan erkekler mevcuttur. Katılımcı, müşteriden ve ailesinden gelen baskıya karşı koyduğunda ise kadın barmene aşık olduğunu iddia eden erkek, yeni sevgilisi ile bara gelmeye başlamaktadır. Katılımcıların yaşamış oldukları buna benzer olaylar heteronormativite etrafinda örgütlenen geleneksel kadınlık ve erkeklik kodlarını yeniden üretmektedir. Aile babası olmaya hazır olan bir erkek her an mağdur edilebilecek olan belki de edilmiş olan bir kadına sevgisini sunuyor ve onu koruyacağı yönünde işaretler veriyorsa, kadının bunu kabul etmesi gerekmektedir. Bar gibi tehlikeli ortamlarda çalışmayan o kadar kadın içinden erkek bu kadını seçmiş ve sevgisine layık görmüştür. Eğer kadın hayır diyerek bu sevgiyi hak etmiyor ise, o zaman, erkeğin sevgisini hak eden diğer kadın ile bara gelerek neyi kaybettiği kadına gösterilmelidir. Erkek “diğer kadın” üzerinden kendi erkekliğini yeniden inşa etmektedir.

Kadın barmenler başlarına gelen taciz olaylarını anlatırken genel olarak taciz eden erkekleri "sapık" olarak tanımlıyorlar. Mesala Ecem (26) işten çıkışını saatlerce bekleyen erkekleri "sapık" olarak nitelendirmektedir. Erkeğin bu davranışı çalıştığı mekândan uzakta oturan Ecem için tehlike ve korku kaynağıdır. "İlk geldiğim yıllarda saatlerce çıkışımı bekleyen sapık erkekler vardı ve evimin de mesafesi uzundu". Benzer şekilde, iş çıkışına kadar onu bekleyen müşterisini merdivenlerde görünce hemen bara geri dönen İlke (22) müşterinin bakışlarını "çok sapıkçaydı" diye tanımlıyor. Katılımcılara göre ancak sapık olan birisi, kadın karşlık vermediği halde ısrar eder. Aklı başında kendini kontrol edebilen birinin saatlerce dışarıda sıcakta veya soğukta beklemesinin imkânı yoktur. Bu ifadeler heteroseksüellik etrafinda örgütlenen hegemonik erkekliğin dışladığı dezavantajlı erkeklere gönderme yapıyor. Hegemonik erkekler kadınlara nazik davranmasını bilen ve kendine güvenen erkeklerdir. Kadınları bu şekilde taciz edenler ise kontrol dışı olan aklın kabul edemeyeceği davranışları gerçekleştiren tehlikeli erkeklerdir. $\mathrm{Bu}$ erkekler korku aracılığı ile kadınları denetlemekte ve iktidarlarını kurmaktadırlar.

İş sürecinde elde ettikleri tecrübelerden dolayı kimlerden uzak durmaları gerektiğini anlayan çalışanlar mevcuttur. Müşterinin bakışından, sipariş vermesinden, sandalyede oturma biçimden, sohbet açmak için seçilen konulardan katılımcılar kimlerin tacizci olabileceği konusunda bir fikre sahiptirler.

"Bi de masaya böyle kişnek kişnek bakarlar. Ha tamam bak kapıcam şimdi muhabbeti kurucam modundadırlar. O bakışları anlamaya başladım artık zaten. Adamın suratın görüyorum; he tamam bu geliyo diyorum artık midem bulanıyo. Bunu erkeğe yapmiyorlar mesela. Ben erkek olsam bu sorunlarla karşılaşmam kafam rahat işimi yaparım. Ama kadinsan zor her yerde" (Asl1, 26). 
Toplumsal cinsiyet eşitsizliği Aslı'nın ifadesinde de kendini gösteriyor. Kadın barmen olmak işe 1-0 yenik başlamak anlamına geliyor. Kadınların yaşamış oldukları taciz olayının barmen olarak çalışmaktan daha çok kadın olmaya atfedilen anlamlarla ilgili olduğu bu ifadede açıkça vurgulanıyor. Aynı iş yerinde çalışan erkek barmenler kadın müşterilerin cinsel ilgilerine maruz kalıyorlar fakat katılımcılara göre erkekler bu ilgiden rahatsız olmak yerine daha çok gurur duyuyorlar. Kadın barmenler kendilerini korumak zorunda hisseder ve temkinli davranmak zorunda kalırken erkek barmenler için bu durum erkekliğin şanındadır halini alıyor. Heteronormativite etrafında şekillenen toplumsal cinsiyet kodlarına katılımcıların ifadeleri ışık tutuyor. Kadınlar cinselliklerini ve bedenlerini sınırlamak zorunda kalırken erkekler heteroseksüelliklerini vurgulama konusunda adeta yarışıyorlar.

\section{Samimiyet Sınırlarının Muğlaklaşması}

Müşteri ile yoğun etkileşim içinde olmak zorunda olan servis işlerinde çalışanların kendi öznelliklerini işe dahil ederek müşterinin mekânda hoş bir zaman geçirmesini sağlaması gerekmektedir. İşle ilgili bilgi ve becerinin yanı sıra samimi ve ilgili tavırlar ile müşteri kendisine özel bir hizmet verildiği hissi ile mekândan ayrılmalıdır. Müşterilere karşı cana yakın, esprili bir tavır ve pozitif bir tutum içinde olmalıdırlar (Brunner \& Dever, 2014; Knights \& Thanem, 2005). Katılımcılar da müşteri memnuniyetini sağlamak için işin gereği olan müşteri ile samimi bir ilişki kurmak veya kuruyormuş gibi bir hava yaratmak zorunda olduklarının bilincindedirler. Eğlenceli olmaları, hızlı diyaloğa girmeleri, müşteriyi havaya sokarak onların tekrar gelmesini sağlamaları gerektiğinin farkındadırlar. Müssterilere onlarla ilgilendikleri ve onları görmezden gelmedikleri mesajını vermeleri gerektiği gibi her müşterinin özel bir deneyim yaşadığını da hissetmesini sağlamak zorundadırlar. Bir barmenden beklenen sadece efsane kokteyller ile müşteriyi bara bağlamak değil, aynı zamanda müşteriyi havaya sokarak orada vakit geçirmesini sağlamak ve güler yüzlü olmaktır. İlke (22) tam da bunu yapıyor. Müşterilerinin uzun süre barda oturmasını veya müdavim sayısının yüksekliğini kokteyllerine değil eğlenceli sohbetine ve samimi olmasına bağliyor.

Katılımcılar için müşteriler iki kategoriye ayrılmaktadırlar: müdavimler ve tanımadıklar. Müdavim müşterilerine daha samimi ve ilgili davranıp onlarla sohbet etmektedirler. Hatta arkadaş olup çalışma saatleri dışında sosyal aktiviteler yaptıkları müşteriler de mevcuttur. Öyle ki bazen müdavim müşteriler katılımcıları diğer müşterinin tacizinden korumaktadır. Bensu'yu (29) barın arka tarafında sigara içerken sözlü taciz eden müşteriden müdavim müşterisi korumakta ve polise şikayet etmek için ona cesaret vermektedir. Fakat, diğer müşteriler için ise işin gerektirdiği kadar samimiyet gösterme konusunda katılımcılar oldukça dikkatlidirler. Müşteri memnuniyetini gözetmek zorunda olduklarının bilincinde olarak çalışanların aklından geçen samimi ilişki ufak tefek gündelik konuşmalar, tebessüm etme ve tokalaşmanın ötesine geçmemektedir.

"Hizmet sektöründe çalışıyosan eğer güler yüzlü olmak zorundasın. Hani biz nasıl kuaföre gittiğimizde kuaförden bizim saçımızı keserken, hani öç alır gibi mi yapmasını mı bekleriz yoksa bize iyi hissettirsin diye mi... Buraya da geliyo insan bi hizmet bekliyo sizden yani güler yüzlü olmak zorundasın, ama bu güler yüzden kastım benim 32 diş haha hihi muhabbet değil kesinlikle. Normal, hani tebessüm deriz ya işte o.." (Asl1, 26).

Bundan dolayı, samimiyetin sınırlarının nerede başlayıp nerede bittiği konusunda müşterilerin çoğunluğu ile barmen arasında görünmeyen bir gerginlik yaşanıyor. Bu noktada, bara oturan müşteriler kadın barmenle samimi bir sohbet etme beklentisi içindeler. Özellikle, müdavim 
müşteriler ile ara sıra sohbet ederken barmenlerin görülmesi diğer müşterilerde de barmen ile sohbet etmenin doğal bir hak olduğu algısını yaratıyor. Bu durumdan oldukça rahatsız olan barmenler, samimi olmadan samimiymiş gibi görünmek için oldukça fazla çaba sarfediyorlar. Aslı'ya (26) göre özellikle bara oturan yalnız müşteriler kadın barmenlerin müşterinin derdini dinlemek zorunda olduğu algısına sahipler "Benle konuşmak için o bara oturmazsın zaten ve benle de konuşamazsın normalde. Müsteri olduğun için sadece ben sana tahammül sinırlarımla söylemem gerekeni söylüyorum zaten" (Asl1, 26). Çalışanların yoğun bir şekilde duygusal emek sürecinde olduklarını anlıyoruz (Hochschild 1983). Kendi duygularını yönetme becerisini gösterdikleri gibi müşterinin duygularını da yönetme becerisine sahipler. Her ne kadar sohbet etmek istemeseler bile duygularını iş yerinin amacına uygun hale getirerek müşterinin memnun ayrılmasını sağlıyorlar. Eğer müşterinin bu beklentisi karşılanmıyor ise bu sefer müşteri barmene kaba, suratsız veya konuşulmaz bir insan olduğu gibi imalarda bulunuyor. Kadın barmenin davranışı ile müşterinin davranışının bir noktada kesişmesi gerekiyor. Katılımcılar "suratsız kadın" olarak etiketlenme riski ile "müsait kadın" olarak etkilenme riski arasında sürekli gidip geliyorlar; çünkü müşteriler ile etkileşimin yoğun olduğu hizmetler sektöründe çalışanların sempatik ve ilgili tavırlarının işin bir parçası olarak değil de müşterilerin gözünde kendisine yönelik bireysel bir ilgili olarak algılanma riski oldukça yüksek (Good \& Cooper 2016). Kadın barmenlerin işin bir gerekliliği olarak sergiledikleri ilgili davranışların müşteri tarafından cinsel bir arzu olarak okunma olasıllğı mevcut. "Yani insanlar şeyi yanlış anlıyo, güler yüz gösteriyorsun müşterin çünkü afiyet olsun falan bi şey ister misiniz gibi şeyler soruyosun ve o sırada gülümsemeni iş atıyo olarak algllyyo insanlar" (Gökçe, 25). "Güler yüzlü çalıştığında hee kesin bana yazıyo diyenlerle çok karşılaşılyorum ve mideni bulandırıyor bir süre sonra" (Buğçe, 22). Katılımcıların ifadelerinden de anlaşıldığı üzere bir kadının çoğu erkek olan müşterilerine ilgi gösteriyor olması cinsel istek olarak karşı taraf tarafindan algılanıyor ve müşterilerin gözünde sınırların muğlaklığı cinsel taciz olasılığını kuvvetlendiriyor.

Katılımcılar, kendi davranışlarının müşteriler tarafından nasıl algılandığını çözmeye çalışmanın yanı sıra müşterinin samimi davranışlarını nasıl okuyacakları konusunda da zorluk yaşıyorlar. Müşteriler aleni olarak bir şey yapmadıkları sürece katılımcılar doğrudan müşteriyi uzaklaştıramadıkları için rahatsız edici bazı davranışları nasıl anlamlandıracakları konusunda karmaşa yaşıyorlar. Müşteriler onlara samimi davrandığında onları elde etmeye mi çalışıyorlar, yoksa sadece iyi vakit geçirmek için kadın barmene karşı dost canlısı mı davranıyorlar sorusu sıklıkla soruluyor. Müşterinin samimi davranışlarına şüphe ile yaklaşma ve ön yargılı olma, iyi niyetli davranışların arkasında kötü niyet arama konusunda kendilerini sorguluyorlar. Neyin iltifat neyin sözlü taciz olduğu konusunda da bir muğlaklığın mevcudiyeti göze çarpmaktadır.

\begin{abstract}
"Aslında bazen ben de ön yargılı olabiliyorum. Ne bileyim bir sürü boş masa var; üç tane adam gelip bara oturuyor hah diyorum ama illa o niyetle yani taciz etme yazma yürüme niyetinde olmayabiliyolar. Böyle ön yargılla bakıp tanışıp arkadaş olduğum insanlar da oldu mesela. Hani ama genel tavır bu olduğu için başta böyle hımm ya hani niye buraya oturdun ki falan diyosun. Bazen insanlar da iltifat etmeyi seviyolar" (Gökçe, 25).
\end{abstract}

Gökçe'nin (25) deneyiminde olduğu gibi samimiyetin sınırlarının muğlaklığı bazı durumlarda müşterinin sevgiliye dönüşme ihtimalini beraberinde getiriyor.

Müşteriler, katılımcılardan samimi tavırlar içinde olması beklentisi ile hareket ederken katılımcılar da müşterilerinden saygı görmek istiyorlar. Katılımcılar, eğer müşterileri onlarla “düzgün iletişime" girerlerse, işin gerektirdiği yüzeysel samimiyeti gösterebileceklerini söylüyorlar. Müşterinin, çalışana yaptığı işin değerli olduğunu hissettirmesi gerekiyor. Hall'un (1993) 
araştırma bulgularına benzer şekilde, katılımcılar müşterilerin özel hizmetkârları olmadıklarını ifade etmektedirler. Aralarında eşitsiz bir güç ilişkisinin olduğunun farkında olsalar da katılımcılar, müşteriler emir verdiğinde emirlerini yerine getiren bir köle olmadıklarını sıklıkla vurguluyorlar. Bundan dolayı, müşterilerin nezaket sınırları içinde içki servisi sırasında teşekkür etmesi ve saygılı davranması barmenlerin beklentileri arasında yer alıyor. Bazı müşteriler bara oturduğunda nezaket kurallarını hiçe sayarak doğrudan "içkimi ver bana" gibi bir ifade kullandıklarında bu tür davranışlar katılımcılar tarafından hoş görülmüyor ve müşteriye ya bir bakış ile ya da nezaket sınırları içinde bir uyarı ile evinde olmadığı, kamusal alanda hizmet satın aldığı hatırlatılıyor.

Katılımcıların ifadeleri barın cinselleştirilmiş bir sosyal mekân olduğu tartışmasını destekler niteliktedir. Kadın barmenler samimi davranmaya çabalamakla beraber cinsel bir nesne olarak görülmemek için de oldukça fazla uğraşıyorlar. Sınırların muğlaklığı/laşması, bar atmosferinin cinselliği destekleyen karakteristiklere sahip olması çalışanları cinsel tacizin hedefi haline getiriyor (Kavanaugh \& Anderson 2009; Riach \& Wilson 2014).

\section{Tacizi Engellemek için Geliştirilen Stratejiler}

Katılımcılar müşterilerin tacizine karşı farklı tepkiler vermektedirler. Good ve Cooper'un (2016) araştırma bulguları ile tutarlı bir şekilde, bu tepkilerin çoğu dolaylı olarak tacizden sakınmayı içermekte ve doğrudan tacizciye müdahale etmek ise daha sınırlı olarak görülmektedir. Dolaylı stratejiler arasında bar masasını fiziksel bir sınır olarak kullanmak, müşterinin davranışını görmezden gelmek, çalışma arkadaşlarına durumu aktarmak, hayalî nişanlılar yaratmak yer almaktadır. Doğrudan stratejiler arasında tacize direnmek veya yüzleşmek ile işverene şikayet etmek yer almaktadır. Good ve Cooper (2016) araştırmasında olduğu gibi, çalışma kapsamında yer alan kadın barmenlerin geliştirdiği stratejilerin bazıları bireysel iken bazıları kolektiftir. Katılımcıların, içinde bulundukları duruma göre tek tip strateji kullanmak yerine aynı anda birçok stratejiyi kullandıkları görülmektedir.

\section{Fiziksel sınır olarak bar masası}

Kadın barmenler kendileri ve müşteriler arasında barın bir sınır oluşturduğunu düşünüyorlar. Müşteri ile daha fazla fiziksel yakınlık içinde bulunmak zorunda olan kadın garsonların, kendilerine göre tacize karşı daha savunmasız olduğunu düşünüyorlar. Her ne kadar barın arkasında olmanın daha korunaklı olduğuna inansalar bile taciz edilmekten kurtulamadıklarını da vurguluyorlar. Müşteri ile aralarında olan fiziksel sınıra rağmen taciz ediliyor olmak kadın barmenleri daha fazla öfkelendiriyor.

\section{"Ben mesela dikkat ederim hani bara birisi oturduğu zaman hani ola- bildiğince böyle şey yapmaya çalışlyorum daha oturulan kısımdan uzak durmaya çalışıyorum" (Asli, 26).}

Bar masasını kendilerine ait bir yer olarak görüyor ve kimin oraya oturacağı konusunda daha fazla kontrol sahibi olmak istiyorlar. Bar masası onlara ait bir yer ise masaya oturan müşterinin de uygun davranması gerekiyor. Taciz eden veya kendi tabirleri ile "uyuz" oldukları müşteriler bar masasına oturmayı hak etmedikleri gibi oturduklarında ise bazı katılımcılar onları görmezden gelmeye çalışıyorlar. Barın kendilerine ait olduğunu düşünseler bile özerk davranma konusunda çekinceleri var. Örneğin "orası benim barım ve gerçekten istemediğim biri oturmamalı normalde işte şey ben yeni yeni kabul ettim böyle istemediğin bi adamı oturtma buraya diye normalde. Ben erkek olsam bu tavrı daha güvenli bi şekilde koyarım mesela yani size hizmet etmek istemiyorum, kusura bakmayın bu sizinle ilgilensin falan gibi... çekiniyorum ne desem falan filan bi yandan" (Gökçe, 25). Müşteri ile aradaki eşitsiz ilişki tacize tepki 
vermemeye ve kabullenmeye yol açıyor. İktidar ilişkisi tacizci ile yüzleşmeyi güçleştiriyor. Sonuçta "müşteri veli nimetimizdir".

\section{Görmezden gelme- İşin bir parçası}

Servis işlerinde çalışanların hem bedenleri hem de işin kendisi cinselleştirildiği için müşterilerin istenmeyen cinsel ilgisi işin ayrılmaz bir parçası olarak görülüyor (Hall 1993; Adkins 1995; Huebner 2008). Benzer şekilde, katılımcılar müşterilerden gelebilecek taciz olaylarının farkındalar ve bunu işin bir parçası olarak görüyorlar. Gökçe (25) bu durumu şu şekilde ifade etmektedir: "hani bu zaten hani bu işe girerken göze alman gereken bi şey aslında, sarhoş insanla uğraşacaksın. Insanlara içki içirip para kazandırıyorsun aslında". Sıklıkla farklı tacizlerle karşılaştıkları için görmezden gelmeye başlamış durumdalardır. Taciz onların iş hayatının rutin bir parçası olmuş. "Her gün en az iki masadan böyle tacizler yaşıyorum. Kovmaya kalksan her birini burada müşteri kalmaz; bi de öyle bi durum var. Alıştım diyebilirim ama sallamıyo değilim, hani oturup ağladı̆̆ım çok zamanlar oldu” (Aslı, 26). Kadın barmen olmanın gereklerinden biri olarak taciz, katılımcılar tarafindan bedensel bir temas, çok rahatsız edici bir durum veya devam eden bir taciz olmadığı sürece kabul ediliyor ve görmezden geliniyor. Dolaylı yollarla müşteriyi uzaklaştırmaya çalışıyorlar. Örneğin, ilgilenmeyerek, müşterinin usanıp veya vazgeçip kendisinin sorunsuzca mekânı terk etmesi amaçlanıyor. Yaşadıkları taciz olayını müşterilerin yüzüne vurmak istiyorlar fakat müşteri kaybı olacağı için sabrediyor ve görmezden geliyorlar. Deniz'in (27) ifadesi ile “bu taciz biliyo musun diyip suratına çakmak istiyosun, ama olmuyo çünkü bir yerden sonra müşteri kaybı olacağını biliyorsun”. Yoğun bir duygusal emeğin içinde olan kadın barmenler duygularını yönlendirerek sakin tavırlar ile uygunsuz müşteriler ile baş etme becerisini kazanmış durumdalar. Öfkeli bile olsalar müşterinin yanında hizmet etmekten memnun olduklarını gösterir bir tavır sergilemek zorundalar (Bolton 2004). Bu tacizi kabul ettikleri anlamına gelmemektedir. Kendilerini sürekli ben ne yaptım da başıma bunlar geliyor diye sorgulamaktadırlar. Bu durum neo-liberal politikaların işin doğasını değiştirmesi ile örtüşmektedir. Her ne şart altında olursa olsun önce müşterinin iyi bir tecrübe yaşaması gelmektedir. Öznelliklerini işin bir uzantısı olarak sunmak zorunda kaldıkları için cinsel tacize maruz kaldıklarında birey olarak mı, yoksa çalışan olarak mı tepki vermeleri gerektiği konusundaki sınırın muğlaklaşması kendilerini sorgulamalarına neden olmaktadır. Aynı zamanda, bar gibi tacizle ilişkilendirilen cinselleştirilmiş sosyal alanda çalıştıkları için bu riskli ortamda çalışmayı kabul ederek en başta bir sıfır yenik başladıklarına inanmaktadırlar.

\section{Kişiselleştirmeme}

Çalışanlar, öznelliklerini işe dahil ettikleri için maruz kalınan taciz olaylarının arkasında farklı nedenler arayarak kendilerini olaylardan uzaklaştırmaya veya kişiselleştirmemeye çalışıyorlar (Good \& Cooper 2016). Good ve Cooper'in (2016) bulgularına benzer şekilde, katılımcılar müşterinin istenmeyen cinsel ilgisini bazı durumlarda alkol kullanımına veya edebi ile içmeyi bilmemeye bağlayabiliyorlar. "Bir gün birisi inanılmaz şarhoştu' 'ş̧ kız baksana sana diyom aloo' falan hani bu insan devlet opera balesinde de bir balet yani aslında, ama insanlar sarhoş olunca inanılmaz değişiyorlar" (Bensu, 29). Tacizci müşterinin sosyal statüsü, bu örnekte olduğu gibi saygın bir mesleğe sahip olması, katılımcıların daha fazla öfkelenmesine neden oluyor. Katılımcılar bu tür durumlarla karşılaştıklarında önce servisi yavaşlatıp müşterinin daha fazla alkol almasını engellemeye çalışıorlar, sonra ise servisi tamamen kesip hesabı alarak göndermeye çalışıyorlar. Bu yolla müşteri ile olan etkileşim en aza indirilerek yaşanan taciz olayı kişiselleştirilmeyip alkolün etkisine bağlı bir olay olarak düşünülüyor.

Kişiselleştirmeme yollarından biri olarak katılımcılar, müşterinin genel hali ve davranışları ile dalga geçiyor ve çocukça buluyorlar. "Mesela o gün de ben sigara içmeye çıkmak için 
bardan çıktım dışarı. Ee şimdi çıkarken bakıyorum adamın bar sandalyesinde dönüyo benim o dönüşümü izliyo. Hemen eline sigarasını alıyo bi telaş sigara falan içmeye çıklyo arkamdan. Yani ne yapıyosun ya? Bu komik değil mi? Çok saçma geliyor bana” (Asl1, 26). Bu yolla kat1lımcılar tacizin etkisini en aza indirmeye ve hissettikleri rahatsız edici duygulardan uzaklaşmaya çalışıyorlar. Tacizci korku duyulan bir kişi olmaktan çıkartılarak daha çok acınacak biri olarak tekrar tanımlanma yoluna gidiliyor. Tabii burada katılımcıların yoğun bir şekilde duygusal emek gerçekleştirmeleri gerekiyor. Müşteriyi pasifleştirme yoluna gidip kendilerini daha iyi hissetmenin yolunu buluyorlar (Good \& Cooper 2016). Pasifleştirme kadın çalışan ve müşteri arasındaki etkileşimin toplumsal cinsiyetçi doğasını da ortaya koyuyor. Erkeklerin saldırgan kadınların ise pasif olarak tanımlanması bu etkileşim sürecinde kendini gösteriyor. İktidar ilişkisi içinde zayıf olan katılımcılar bu yol ile kendilerini güçlü hissediyorlar ve yaşadıkları deneyimi iş ortamının bir parçası olarak görüp özne olarak zedelenmenin önüne geçmeye çalışıyorlar.

\section{İş arkadaşlarından yardım isteme: "Erkeğe karşı erkekle birlikte mücadelenin imkânı/ imkânsızlığı"}

Bazen bireysel olarak taciz ile baş etmeye çalışmak yerine kolektif olarak baş etme yolu tercih ediliyor. Katılımcılar erkek barmenlerden veya diğer çalışanlardan yardım istiyorlar. Müşteriye servis yapmamak müşteri kaybı olacak ve gerilimi artıracağı için, katılımcılar öncelikli olarak taciz eden müşteriyi görmezden gelip uzak durmaya çalışıyor ama sonrasında diğer erkek barmene servisi devrediyorlar. Bedensel temas etmeye çalışan müşteriden uzak duran Gökçe (25) gerilimin yükselmemesi için beraber çalıştığ 1 erkek barmene müşterileri transfer ediyor. "Bazen yanımda B. oluyo barda tek çalı̧̧ıуyorum sürekli olduğu zaman 'direkt onlara sen bak'... ya da fark ediyo zaten müdahale ediyo sıkıntılı durum olduğu zaman 'hadi sen geç bi sigara iç' ya da 'sen bu tarafa gel falan gibi'” Erkek barmenlerden yardım isteme kolektif olarak tacizle baş etmenin bir yolu olsa bile iş yerindeki toplumsal cinsiyet hiyerarşisinin göstergesidir. Bu bağlamda, erkek barmenlerin sorunlu müşterilerle baş etme gücüne sahip olan kurtarıcı erkekler olarak görülmesi ataerkil kodların tekrar üretilmesini sağlıyor.

\section{Bana dokunmayın ben sahipliyim: Bir strateji olarak nişan yüzüğü}

Kadın barmenler rutin işlerini yaparken sıklıkla cinsel tacizle karşılaşıyor ve bunu işin bir parçası olarak kabul edip çoğu zaman görmezden geliyorlar. Fakat, cinselliği teşvik eden barın kültürel atmosferinde geleneksel toplumsal cinsiyet kodlarının ve heteronormatif değerlerin hâkim olduğunun farkında olarak kadınlıklarının sürekli sorgulandığı bu ortamda geleneksel kadınlık kodlarına uygun kadınlar oldukları mesajını karşı tarafa vermek için ince stratejiler izliyorlar. Ataerkil sistemin makro ve mikro yansımanın en belirgin görüldüğü evlilik kurumuna giden yolda adım attıklarını göstermek için nişan yüzüğü takıyorlar. Kadınlar için riskli kabul edilen, alkol ve müziğin olduğu, erkeklerin “avlanmak” için geldikleri mekânlarda çalışan kadınlar olsalar da aslında onlar bir erkeğin eşi olma yolunda adım atmış olan kadınlar oldukları mesajını vererek "müsait kadın" olmadıkları vurgusunu yapıyorlar. Ataerkil kodları kullanarak kendilerinin bir erkek tarafından sahiplenildiği ve koruma altına alındığı mesajını müşterilere veriyorlar. Barmen kadınlar nişan yüzügü takarak önce kendilerinin sahiplenildiği mesajını sembolik olarak karşı tarafa veriyorlar; sonra da hayalî nişanlı hakkında meraklı müşterilere açıklama yapıyorlar. İşe ilk başladığı yıllarda müşterilerin tacizinden kurtulmak için hayalî sevgili üreten ve sevgisinin sembolü olarak gümüş yüzük takan Aslı (26) daha sonraki yıllarda ilişkisinin ne kadar ciddi olduğu ve evliliğe doğru yol aldığını göstermek için tek taş yüzük takmaya başlamış. Ama tek taş yüzük tacizci müşterilerin onun hayatını ve hayalî nişanlının erkekliğini sorgulamalarının önüne geçememiş. "Nişanlın ne zaman gelip seni buradan alacak", "senin böyle yerlerde çalışmana kızmıyor mu" gibi sorularla sürekli muhatap olmak zorunda 
kalan Aslı hayalî nişanlı için hayalî açıklamalar üretmeye devam etmektedir. Benzer şekilde, Ecem de (26) kendisini yüzük ile koruma altına almaya çalışıyor. "Ya ben zaten gece çalışırken yüzük takardım bu durumu (tacizi) aza indirmek ve engellemek için. Sevgilim olsa da olmasa da takıyodum o yüzügü̈. Nişanlı olduğumu söylüyodum yalandan. Adımı da herkese farklı söylüyordum, yaşımı, hayatımı. Gündüz takmıyordum ama mesela" (Ecem, 26).

Bazen de tacizci ile yüzleşmek yerine hayalî sevgilinin sosyal medya hesaplarını kontrol ettiği gibi bahaneler uydurarak tacizin devam etmesini engellemeye çalışıyorlar. Sosyal medyadaki fotoğraflarının hepsinin bir müşterisi tarafından birkaç saat içinde beğenildiğini gören Deniz (27) hemen müşteriyi engelliyor. Fakat bu taciz olayı ertesi gün bara taşınıyor ve müşteri niçin engellediği konusunda Deniz'e hesap sorduğunda Deniz "haberinin olmadiğg ve sevgilisinin engellediğini” söylüyor. Hayalî bir sevgili Deniz'in kurtarıcısı oluyor. Fakat Deniz neden suçlu gibi davranarak yalan söylemek zorunda kaldığını da sorgulamadan edemiyor.

Tacize maruz kalmamak veya maruz kaldıkları tacizin devam etmemesi için kadınlar taciz eden kişiye karşı bahaneler uydurmanın bir yolu olarak hayalî erkek nişanlı veya sevgili üretiyorlar. Erkeklerin tacizine karşı koymak için başka bir erkeğin gücünü sembolik olarak kullanmak zorunda kalmak kadınların sistemi sorgulamasına neden oluyor. Mağdurken neden suçlu gibi hissettikleri, taciz eden onlarmış gibi kendilerini neden savunmak zorunda kaldıkları sorusu zihinlerini meşgul ederken, kurtarıcı bir erkek figürü yaratmanın da heteronormatif düzeni pekiştirdiğinin farkındalar.

Hayalî sevgililerin dışında kadın barmenlerin sevgilisi olduğunda sevgililer onların gece çalışmalarını istemiyorlar, çünkü kadınlar için gece çalışmanın tehlikelere açık olduğu düşüncesi hâkim. Çalışma saatlerini geceden gündüze alan katılımcılar mevcut. Kadınlar tacizden kendilerini korumak, hayalî veya gerçek erkeklerin koruması altında oldukları mesajını karşı tarafa vermek zorunda kalıyorlar. Tabii bunu yapmak zorunda olmaları kadınla ilgili toplumsal söylemleri sorgulamalarına da neden oluyor. Erkek olsalardı ne taciz ile uğraşmak zorunda ne de hayalî nişanlı üretmek zorunda kalacaklardı. Hayalî sevgili veya nişanlı üretmek kadınların toplumsal olarak güçsüz ve savunmasız olduklarının da işareti. Yaratılan hayalî nişanlı veya sevgilinin hemcins değil karşı cinsten biri olduğu dikkate alındığında kadınlar heteroseksüelliklerini vurgulayarak ataerkil sistemin geleneksel toplumsal cinsiyet kodlarını da tekrar pekiştiriyorlar.

\section{Giyim kuşamla beden disiplini}

Kadın bedeninin cinsellik ile özdeşleştirilmesi iş yerlerinde kadınların bedenlerinin cinsel arzu nesnesi olarak tanımlanmasına neden olmaktadır. Kadının bedeni ve cinselliği iş yerinde sürekli "problem yaratan” ve “işin akışını engelleyen” bir unsur olarak görüldüğünden kadınların cinsellikleri ya baskılanarak ya da öne çıkarılarak işe uygun hale getirilmelidir (Acker 1990; Bruner \& Dever 2014). Hizmet işinin toplumsal cinsiyetlendirilmiş ve/veya cinselleştirilmiş doğası kadın bedenini cinsel bir nesne olarak alkolün ve eğlencenin olduğu yerde sunmaktadır. Cinselleştirilmiş hizmet işlerinde çalışan kadınların giyimleri, saç ve makyajları sürekli erkeklerin bakışı ile denetlenmektedir. Katılımcılar iş yerinde cinselliklerini görünmez hale getirmek için giysilerini sınırlandırmaktadırlar. Müşterilerin onları cinsel bir nesne olarak görmemeleri için yoğun çaba harcamak zorunda kalmaktadırlar. Aynı zamanda, giysiler üzerindeki bu sınırlamalar cinsel saldırıya uğrayan kadın mağdurlarla ilgili toplumsal söylemi de pekiştirmektedir. Riskli kabul edilen bir ortamda çalıştıkları için taciz edilmeyi hak etmedikleri mesajını giysilerini denetleyerek vermeyi amaçlıyorlar. Mağduru suçlama üzerine oluşturulan söylemler katılımcıların zihninde yer etmiş durumda. Patronun, iş arkadaşlarının, ailelerinin 
gözünde "măgdur iken suçlu duruma düşmemek için" kendi kendilerinin gözetleyicisi ve denetleyicisi olmuş durumdalar. Aslı (26) kendi kendine kıyafetlerini sınırlama konusunda telkinde bulunuyor. Başına bir şey gelirse başına gelenden sorumlu tutulmaması gerektiğini düşünüyor. Bu kadar önleme karşı hala taciz ediliyorse daha ne yapabileceğini kestiremiyor. Taytların üstüne uzun tunik veya hırkalar giyiliyor, dekolte verilmemesi için çok çaba sarf ediliyor hatta bu tür kıyafetler giyilmiyor, şort giyilmemeye çalış1lıyor. Etek, şort veya askılı giydikleri zaman müşterilerin bakışlarından rahatsız oluyorlar. Başka zamanlarda onlara iltifat etmeyen müşteriler bu tür kıyafetler giyildiğinde iltifat ettiklerinde çok rahatsız oluyorlar çünkü bu iltifatın altında başka şeyler yattığını seziyorlar. Bundan dolayı, bu tür kıyafetleri nadiren giyiyorlar. Herhangi bir yanlış anlaşılmaya yol açmamak için yoğun çaba harcarken oluşabilecek iş kazalarına karşı önlem alıyorlar. Hayatı boyunca hiç kemer kullanmamış olan Bensu (29) son üç yıldır kemer kullanıyor, çünkü yerden birşeyler alırken veya raflara uzanırken hiç açılmayan pantolonun açıldığını fark ediyor. Buğçe (22) kendi giyim tarzını erkeklere benzetiyor. Eğilip kalkarken sorun yaşamamak ve müzik sesinin yüksekliğinden dolayı sipariş alırken müşteriye yakınlaşmak zorunda olduğundan sürekli bir yerleri açıldı $\mathrm{m} 1$ diye endişe etmektense erkek gibi giyinerek bu tür endişelerden kendini kurtarmış oluyor. Gökçe (25), sert görünmeye çalıştığına ve "klz gibi giyinen gösterişli” bir kadın olmadığına dikkat çekiyor. Gökçe’nin "klz gibi giyinen gösterişli” kadın vurgusu aslında mağdurun giysisi ile cinsel taciz arasında kurulan ilişkiyi de gözler önüne seriyor. Taciz edilen kadınların "açık saçık giyinerek" sanığı teşvik ettiği aslında sanığın masum, mağdurun başına geleni hak ettiği söylemini bu vurguda görüyoruz. Kendisini gösterişsiz kadın olarak tanımlayarak, giysisi, davranışları veya tutumları ile taciz edilmeyi hak ettiği algısı yaratılan diğer kadınlardan ayırıyor. Bedenlerini kapatarak dikkat çekici olmamak ve cinselliklerinden arınmak için yoğun bir çaba sarf ediyorlar. Bir taraftan da bedenlerini kapatmanın tacize çözüm olmadığının da farkındalar. Aslı'ya (26) göre ne fiziğin, ne güzelliğin ne de kıyafetin önemi var: "oturup ağladiğım çok zamanlar oldu ben bunları hakkedecek ne yaptım, sonra kendimi suçluyorum hani dizime kadar giydim artık. Diyorum her yerim kapalı hala niye böyleler ki ben kapanmak zorunda değilim ...hani bir bakış görüyorsun adamın umrunda değil sen ne kadar kapatırsan kapat insan içinde yine hayal ediyo yani”. Katılımcılar tacizin giysi ile ilişki olmadığının farkında ve baskın söylemi eleştiriyor olsalar bile pratikte mağdur kadınlarla ilgili betimlemeleri pekiştiriyorlar. Giysilerini, makyajlarını, saçlarını disipline ederek geleneksel kadınlık normlarına uygun kadınlar oldukları mesajını vermek için yoğun bir çaba içindeler.

\section{Patronların Tacize Tepkileri: Önce Müşteri mi Gelir?}

İşverenlerin müşterileri mi yoksa çalışanlarını mı öncelediği kadınların tacize karşı duruşlarını belirleyen süreçlerin başında geliyor. Her ne kadar kadınlar fiziksel temas veya onları çok korkutan bir durum olmadığı sürece kendileri veya iş arkadaşları ile tacizle baş etmeye çalışıyor olsalar bile işverenlerin bu konudaki tutumları kadınların verecekleri tepkilerin derecesini etkilemektedir. Katılımcıların anlatılarından iki tür işveren olduğu anlaşılmaktadır: müşteri kaybını göze almamak için tacizi görmezden gelen ve çalışanlarını koruyan ve müşteri kaybını göze alan.

Kadın barmenler iş yerlerinde yaşadıkları tacizleri işverenlerine bildirmelerine rağmen, bazı patronların hem ataerkil yapıya hem de neo-liberal politikalar ile değişen servis hizmetlerinin niteliğine uygun tepkiler verdiklerini görüyoruz. İşverenler müşteri memnuniyetini öncelediklerinden dolayı müşteri kaybını göz önüne alamadıkları için kadın barmenlerin yaşadıkları tacizleri görmezden geliyorlar. Hem kadın barmenlerin ne kadar namuslu oldukları vurgusu tekrar bu süreçte inşa ediliyor hem de tacizci bir müşteri uğruna diğer müşterilerin kaybedile- 
meyeceğine işaret ediliyor. Kadın barmenlere "evet sorun sende değil müşteride" mesaj1 verilmekle beraber tacizin "çok da büyütülecek bir şey olmadiğı” da alt söylem olarak veriliyor. Hatta tacizci müş̧eri ile baş etmek için işverenin bir müdahalede bulunması iki erkeğin erkekliklerinin mücadelesi anlamına geliyor. Eğer işveren bir erkek olarak koruması altında olan kadın barmene bir müşterinin uygunsuz davrandığını kabul ederse, ailesini korumak zorunda olan bir erkek gibi müşteri ile yüzleşmek zorundadır. Patronlar taciz olaylarını görmezden gelerek kendi erkekliklerini de sorgulamaya kapatıyorlar. Örneğin Aslı (26) daha önceki patronunun tacizi kendi gözleri ile gördüğü halde bile görmezden geldiğini ifade ediyor. Patronu, barın demirine tutunarak Aslı'ya sürekli öpücük atan öğretim üyesi olan müşteriyi görmezden geliyor. Aslı, patronu ile yüzleşip niçin görmezden geldiğini ve adamı uzaklaştırmak için bir şeyler yapmadığını sorduğunda ise patronunun "gördügünü kabul ederse adama karşı şiddet kullanmak dışında başka bir yolu olmadı̆̆ını ama bir müşteri için ă̆zına kadar dolu bir barı kaybedemeyeceğini" belirttiğini söylüyor. Bir taraftan da, Aslı'nın asla müşteriyi teşvik etmek için bir davranışta bulunmadığı ve ne kadar namuslu olduğu vurgusu yapılıyor. Bu vurgudan kadın barmenlerin cinselliklerinin emeklerinin bir parçası olarak iş yerine girdiğini ve geleneksel kadınlık kodlarına uygun bir şekilde cinselliğin sergilendiğini anlıyoruz. Patronu görmezlikten gelerek hem erkekliğini korumuş hem de müşteri kaybını önlemiş oluyor. Kendini bu ve benzer durumlarda güçsüz hisseden ve patronunun çıkarcı davranışlarından yorulan Aslı kendini daha güvende hissettiği, patronlarını "abi" diye nitelendirdiği barda çalışmaya başlıyor. Patronların "abi" olarak nitelendirilmesi de barmenlerin müşteri karşısında korunmaya muhtaç olduğunu gözler önüne seriyor. Bu tanımlamalar, iş yerindeki ilişkiler ile ataerkilliğin en önemli taşıyıcısı olan aile içindeki ilişkiler arasındaki benzerliğe dikkat çekiyor. Aile içinde abilerin kız kardeşlerini tehlikelere karşı koruyup kollayarak onları güvende hissettirmesine benzer şekilde, abi gibi davranan patronlar da çalışanlarına benzer bir güven hissi veriyor. $\mathrm{Bu}$ şekilde heteronormatif değerler ile erkeğin güçlü, kadının kırılgan ve korunmaya muhtaç varlık olduğu söylemi iş yerindeki gündelik pratikler içerisinde de yeniden üretiliyor.

Mekânın patronlarının çalışanlarla kurmuş olduğu ilişki ve tacize bakış açıları kadın barmenlerin tacize karşı direnç göstermelerine olanak sağlıyor. Görüşmelerden anlaşıldığ kadarı ile patronların tacizciye müdahale etmesi müşteri kaybı olarak görülüyor; fakat bazı patronlar katılımcıları ve diğer kadın çalışanları rahatsız eden müşterileri bara almamak veya bardan çıkarmak gibi yolları kullanarak müşteri kaybını göze alıyorlar. Bu tür barlarda kadın barmenler öncelikle dolaylı yoldan taciz edenlerle baş etmeye çalışıyorlar. Taciz edenle ilgilenmemek, erkek barmenin veya diğer çalışanların ilgilenmesini sağlamak, daha çok uzak durma veya görmezden gelme stratejisini benimsiyorlar. Fakat tacizin devam ettiği durumlarda ise kendileri yüzleşmek yerine barın patronları veya görevlileri müdahale ediyor ve müşteri bardan atılıyor veya müşterinin bara girmesi engelleniyor. Daha önce çalıştığ yerde müşterinin sözel tacizine maruz kalan İlke (22) durumu patronlarına bildirdiğinde, patronlar doğrudan müdahale ediyor ve para almadan müşterinin bardan gitmesini sağlıyorlar. Patronların bu tutumu kadınların kendilerini iş sırasında daha rahat hissetmesini sağlıyor. Ecem (26) ve Deniz (27) kendilerini tacizcilere karşı savunan patronlarını "belalı veya mafyatik tipler" olarak tanımlıyorlar. Kendisini Eryaman'a kadar takip eden müşteriyi ertesi gün bara çağırarak durumu patronlara söyleyen Deniz (27) müşterinin tacizi bırakmasının nedenini patronların "biraz mafyavari insanlar" olmasına bağlıyor.

"Asılan eden tiplerle ilgilenmemeye çalışırız bilerek kendisi vazgeçip gitsin mekândan. Yoksa patronlarımı biraz belalı tipler onlar kovmak zorunda kalıyo. Bi de burda o tarz müşsterileri çıkarabiliyorsun direk yani müşteri kaybı olarak görülmüyor. İlk geldiğim zamanlarda böyle 
durumla oluyodu saatlerce çıkışımı bekleyen sapık erkekler vardı. Bu durumdan kurtulmak için servis koydu patronumuz. Artık sıkıntı oImuyo..” (Ecem, 26).

Eğer patronlar tacize karşı katı tavır sergiliyor iseler, o zaman kadın barmenler taciz eden müşteri ile yüzleşebiliyorlar. İlke (22) kokteyl servisi sırasında göğsüne dokunan orta yaşlı bir müşteri ile doğrudan yüzleşiyor ve onun bedenine değmesinin taciz olduğunu söylüyor. Hatta bu tepkisini alçak bir sesle değil herkesin duyabileceği yüksek bir sesle gösteriyor. Müşteri İlke'yi yanlış anladığı yönünde ikna etmeye çalışsa da patronlarının onu yarı yolda bırakmayacağını bildiği için müşteriyle olan tartışmasını diğer çalışma arkadaşlarını da yanına çağırarak devam ettiriyor. Müşteri barı terk ediyor. Ama İlke de patronlarını belalı tipler olarak tanımliyor.

Kadın barmenlerin tacizci ile yüzleştiği durumlarda ya patronlar "abi” ya da "belalı" olarak tanımlanıyorlar. Koruyucu veya gözünü budaktan esirgemeyen erkek patronlar ile çalışanlar arasındaki ilişkide maskülen değerlerin işin bir parçası olarak yaratıldığı görülüyor.

\section{Tacizle Baş Ederken İşini Yapmaya Çalışmak}

Kadın barmenlerin mesleki bilgi ve becerileri müşterileri tarafından sürekli teste tabi tutuluyor. Müşteriler olmayan kokteylleri sipariş ederek, içtiği kokteylin tarifini sorarak, kokteylin yanlış hazırlandığını iddia edip bir öğretici edası ile kendi hazırlamaya çalışarak kadın barmenlerin işe uygunluklarını sorguluyorlar. Örneğin, Deniz'in (27) kendisinin de en çok sevdiği ve en iyi bildiğini söylediği cin tonik’te bile müşteriler çoğu zaman malzeme oranlarının yanlış olduğunu iddia ediyorlar. "En büyük sıkıntım şey barın içinde bi tane kadın var ve o beceremez bi şey. Genelde güvenilmiyo. Öyle bir algı var onu yıkmaya çalışıorum. Şu an bu arada şey barmasters diye bi yarışma var onda finale çıktım" (Gökçe, 25). Barmenlerin rekabet ettiği bir yarışmada yeteneklerini sergileyip finale kalan Gökçe bile sürekli yaptığı işin sorgulanmasından şikayet ediyor.

Katılımcılara göre erkek barmenler bu tür davranışlara çok ender maruz kalıyorlar. Erkek barmenler müşteriye içecek konusunda tavsiyede bulunduğunda müşteri çoğu zaman itiraz etmeden kabul ediyor. Katılımcılar bu tür tavsiyelerde bulunduklarında ise direnç ile karşılaş1yorlar. Fakat müşteri tavsiye edilen kokteyli çok beğenirse bu sefer de sen bir kadın olarak bu kokteyli nasıl yaptın der gibi hayrete düşüyorlar. Müşterilerin hayret etmelerinin arkasında iş gücü pazarının toplumsal cinsiyete göre ayrışması yatıyor. Erkeklerin, malzeme bilgisi isteyen ve alkol oranlarının hassaslıkla ayarlanmasını gerektiren barmenlik işinde daha başarılı olacağı düşünülüyor. Sonuçta aklın temsilcisi olan erkek, malzeme bilgisini ve matematiği kullanarak ancak muhteşem kokteyller hazırlayabilirken bu bilgiden yoksun olan kadının başarılı olması ise ancak şans eseri görülüyor.

Barmenliğin erkek işi olarak görülmesi, iş gücü pazarının kadın ve erkek işi olarak ayrışması ve ataerkil yapının kadınlara daha fazla gündüz işlerini uygun görmesinin sonucudur. Gece işleri kadınlar için tehlikeli olarak kabul edilirken, hele ki alkol ve eğlencenin birleştiği, loş ortamlarda kadınların varlığı ister müşteri ister çalışan olsun cinsellik ile ilişkilendirilmektedir. Kadınların "doğalarına uygun” ve güvenli işlerde çalışmaları beklenir. Gece ekonomisi içinde olan barmenlik gibi işler ise tehlikeli olduğundan kadınlar için uygun görülmez. Katılımcılar bu söylemlerin oldukça farkındalar. Barmenliğin fiçı kaldırmak gibi bazı fiziki zorluklarının dışında kadınlar tarafından kolaylıkla yapılabilecek bir iş olduğuna hatta kadınların bu işte erkeklere göre daha başarılı olduğuna inanıyorlar. Fakat kadınlara bu mesleğin uygun görülmemesinin nedeninin kadınların tercih etmemesinde değil toplumsal yapının baskısı ve iş gücü 
pazarının kadın ve erkek işi olarak ayrıştırılmasında yattığını düşünüyorlar. Barın cinselleştirilmiş sosyal bir alan olması kadınların bu meslekte çalışmasının önündeki engellerin başında geliyor. Buğçe (22) "Türkiye toplumda kadınların gece evlerinde olmalart isteniyo çünkü şey sapık bi toplumdayız. Kadınlar istediklerini giymek istiyo istediği saatte çalışmak istiyo, ama gece olunca sarhoş insan çok fazla, tehlike oranı artıyo o yüzden kadınların kendilerini koruyamayacakların düşündükleri için daha böyle gündüz normal işlerde çalışmaları isteniyo. Gece direk erkeklerin iş alanı gibi görülüyo”. Gece işlerinin kadınlar için tehlikeli olduğu algısına vurgu yaparken Buğçe (22), Ecem (26) ise tüm mesleklerin ataerkil yapı tarafindan cinsiyetlendirildiğini vurguluyor: "genelde nasıldır erkek çalışır kadın evinde çocuğuna bakar yemeğini pişirir bunun çok benimsenmesi ve çok uzun zamandan beri sürmesiyle alakalı bence". İşücü pazarında kadın ve erkek işi olarak işlerin cinsiyetlendirilmesi kadınların kadın mesleği olarak görülen birkaç alana sıkışıp kalmasına sebep olurken bu alanların dışında çalışmak isteyen kadınlar da işlerini yapma sürecinde hem ayrımcılığa hem de tacize maruz kalıyorlar. Bensu (29) dünya genelinde cinsiyetlendirilmiş olan mesleklerin belki feminizm ile yenilebileceğini düşünüyor. Barmaster yarışmasında finale kalan Gökçe'nin (25) başarısını feminizmin bir işareti olarak görüyor ve kadınlar bu alana daha fazla girdikçe meslekte yaşanan ayrımcılı̆̆ın ve tacizin azalacağına inanıyor.

\section{Tacizi Toplumsal Yapı ile İlişsilendirmek}

Radikal feministlerin vurguladığı gibi bireysel olan her şey politiktir. Bu bağlamda, kadınlar yaşamış oldukları taciz olaylarını ataerkil sistemin bir yansıması olarak görmektedirler. Ne kadar giyinirlerse giyinsinler, müşterilerle ne kadar sınırlı bir ilişki kurmaya çalışırlarsa çalışsınlar sadece barda çalışmanın tacize uğramak için yeterli olmadığına, daha çok tacizin arkasında ataerkil sistemin kadınlığa yüklediği anlamların yattığına inanmaktadırlar. Kadınlara yönelik taciz ataerkil değerler sistemi tarafindan normalleştirilmektedir. Eğlenmeye veya çalışmaya gece dışarı çıkan, hava kararınca evinde olmayan kadınların başlarına gelen şeyleri hak ettiğine yönelik olan inanış, tacizin temelini oluşturmaktadır. Katılımcılar yaşadıkları taciz olaylarını sadece barmen olmalarına bağlamamakta benzer olayları çalışma saatlerinin dışında kamusal alanda da deneyimlediklerine işaret etmektedirler. Deniz (27) "barda çalışmamla alakalı bi şey değil kesinlikle. Her an başımıza bu tür tarz şeyler gelebiliyo". Evlerinin yakınlarındaki markete giderken, otobüse binerken, takside taciz olayları yaşamaktadırlar. Aslı (26) "zaten günümüzde etek giydin tahrik ettin, tayt giydin tahrik ettin gibi tacizi normalleştiren durumlar var. E ben ne giyeyim? Bir erkek şort giydiğinde beni tahrik etmiyor açıkçası niye onu ediyo? Bak şimdi karısı evde sevgilisi yanında ordan gözüyle sana iş atıyo. Bu mu şimdi normal? Çünkü neden sen o saatte ordasın sen kolay lokmasın zaten bi de geç çıkıyosun işten oo bi de alkollü yer zaten basit insansın... erkek zihniyetini temizlemek lazım” Deniz (27) "barda çalıştığım için onun zihinde uyanan şey... sen basit kızsın rahatsın. Demek ki ailesi karışmıyor rahat biri ben alırım bunu gibi düşünceler". Hem barda hem de kamusal alanda yaşanan taciz olayları heteronormatif değerler ile ilişkilidir. Cinselliğin kadın bedeni ile özdeşleştirilmesi kadınların çalışma hayatında sınırlamalar getirdiği gibi kamusal alanda ne zaman ve nasıl hareket edeceklerini de sınırlamaktadır. Cinselleştirilmiş sosyal alan olan barda çalışan veya eğlenmeye giden kadınlar erkeklerin gözünde kolay bir av olarak görülmektedir Heteronormativite erkeklerin cinselliklerini özgürce yaşamasına olanak tanırken kadınların cinselliklerini ise sürekli sınırlamaktadır. Sokakta, markette, bar ortamında heteroseksüelliği teşvik eden değerler tarafından kadınlık ve kadın cinselliği sürekli denetim altına alınmaktadır. İster gündüz ister gece kabul edilebilir kadınlık kodlarına uygun davranmayan kadınlar "müsait kadın" veya "kolay lokma" olarak tanımlanırlar. Gece ekonomisi içinde çalışan, gece geç saatte 
dışarı çıkan, karanlık sokaktan geçen, biraz gösterişli giyinen veya taksiye tek başına binen kadınlar koruyucu bir erkek figürü yanlarında olmadığı için en başta kabul edilebilir kadınlık sergilememektedirler. O zaman ister barda ister başka yer de başlarına geleni hak etmiş olarak görülmektedirler.

\section{Sonuç}

Emek sürecindeki dönüşümler çalışanların bilgi ve becerisinin yanı sıra iş yerine uygun davranmaları, görünmeleri ve tutum sergilemelerini işin bir parçası haline getirerek çalışanlarını giderek güçsüzleştirmektedir. Gülümsemek, giyiniş ve duruş ile estetik bir görünüşe sahip olmak emek sürecinin artık doğal bir parçası haline gelmiştir. Bu süreçler toplumsal cinsiyetten ve cinsellikten arındırılmış gibi gösterilen iş yerlerinin heteronormativite temelinde nasıl örgütlendiklerini görmeyi giderek zorlaştırmaktadır. Çünkü işe uygun kadınlık ve erkekliklerin yaratılması ve cinselliğin işe uygun olarak sunulması işin gereği halini almıştır. Müşteriler ile yoğun etkileşimin olduğu bar işlerinde ise yaratılan kültürel atmosfer ile çalışan ve müşteri arasındaki sınırların muğlaklaşması çalışanların bedenlerinin cinsel arzu nesnesi haline dönüştürülmesinin yolunu açmıştır. Bu çalışmada, kadın barmenlerin deneyimlerine odaklanılarak cinsel tacizden kaçınmaya çalışılırken ataerkil yapının ve heteroseksüelliğin yeniden üretilme süreci ve araçları anlaşılmaya çalışılmıştır.

Ataerkil sistem tacizi meşrulaştırarak kadınları kontrol etmenin bir aracı olarak kullanmaktadır. Kadınların bedenleri ve cinsellikleri sürekli erkeklerin bakışları altında her an tacize uğrama ihtimalini gündeme getirerek kontrol etmektedir. Kontrol mekanizması olarak çalışan taciz aracılığı ile kadınlar iş gücü pazarından el çektirilmekte veya kadınların yoğun olarak çalıştıkları ve güvenli olduğu düşünülen mesleklere ve işlere yönlendirilmektedir (Acker 1990; MacKinnon 1979). Gece ekonomisi içinde yer alan barmenlik gibi kadınların yeteneklerini gösterdikleri ve yorucu olmakla beraber fabrika işine göre daha yüksek ücretler alabilecekleri mesleklerden ise "müsait kadın" imgesi yaratılarak uzak tutulmaktadırlar.

$\mathrm{Bu}$ çalışmada kadın barmenlere odaklanılmakla beraber sorulması gereken giderek sayıları artan hizmetler sektöründe çalışan erkeklerin de benzer deneyimler yaşayıp yaşamadıklarıdır. Örneğin, erkek barmenler söz konusu olduğunda kadın müşteriler göze hoş görünen, flört eden erkek barmenler tarafindan $\mathrm{m}$ içkilerinin sunulmasını tercih etmektedirler? Müşteriler servis hizmetlerinde çalışan erkek ve kadınlardan benzer şeyler mi istemektedirler? Erkek müşteriler kadın çalışanları cinsel arzu nesnesi haline dönüştürürken kadın müşteriler erkek çalışanlara benzer bir arzu ile mi bakmaktadırlar? İş yerinde cinsellik ve tacizden bahsedildiğinde kadınlar odak noktasıdır fakat iş yerinde cinselliğin nasıl inşa edildiği ve güç ilişkilerinin bu süreçteki yerini anlamak için kadınlarla beraber erkeklerin de araştırmaya dahil edilerek kavramsal tartışmalarının derinleştirilmesinin önemli olduğuna inanılmaktadır (Warhurst \& Nickson 2009).

Neo-liberal politikaların emek sürecinde yaratmış olduğu dönüşümler duygusal emeği (Hochschild 1989) zorunlu kılmakla beraber estetik emeği de (Mears 2014) zorunlu hale getirerek iş yerlerindeki toplumsal cinsiyet kodlarını ve cinselliği farklı stratejiler ile tekrar üretmektedir. Çalışanların görünüşleri de işin bir parçası haline gelmekte ve çalışanların bedenleri markaların taşıyıcı olmaktadırlar. Çalışanlar hem doğru tutum ve davranışlara hem de iş yerinin temsilcisi olarak doğru görünüşe sahip olmalıdırlar. İş yerleri, müşterilerin duyularına hitap etme kapasitesi olan çalışanları öncelikli olarak tercih edip, eğitimler ile çalışanların görünüşlerini iş yerinin amacına uygun hale getirmektedir. Örneğin, AVM'de spor mağazasında, tasarım ürünlerin satıldığı mağazada veya teknoloji mağazasında çalışan satış elemanlarını düşündüğümüzde markanın temsilcisi olarak vardırlar. Çalışırken beden duruşlarının nasıl 
olacağı, nasıl giyinecekleri, nasıl makyaj yapacakları, hangi renklere ağırlık verecekleri, tıraşın hangi sıklıkla olunacağı ve müşteriye hangi sözcüklerle hitap edeceklerine kadar eğitime tabi tutulmaktadırlar. Çalışanların duyguları ile beraber görünüşleri de markanın bir parçası haline dönüşmektedir (Warhurst \& Nickson 2009). Hegemonik kadınlık ve erkeklikler markanın taşıyıcı olarak çalışanın bedeninde üretilmektedir.

Sorgulanması gereken bir başka nokta ise emek sürecinin heteronormatif değerler üzerinden hegemonik kadınlık ve erkeklik tanımlamalarını nasıl örgütlediğidir. İş yerinde heteroseksüelite duygusal ve estetik emek ile yaratılıp hegemonik kadınlık ve erkeklikler emek sürecinin bir parçası haline gelirken, eş cinsel çalışanların cinsellikleri ve toplumsal cinsiyetleri cinselleştirilmiş emek sürecinde dışlanmaya mı maruz kalmaktadır? Dışlanmadan kurtulmak için çalışanlar kendilerini heteroseksüel kadınlar ve erkekler olarak mı lanse etmek zorunda kalmaktadırlar? Eş cinsel müşterilere hizmet veren eğlence mekânlarında, otellerde veya barlarda çalışanların emekleri benzer şekilde cinselleştirilerek eşitsiz ilişkilerin ve yapının devam etmesine katkı mı sağlamaktadır? Eş cinsel çalışanların tacizden sakınma stratejileri nelerdir? Bu gibi soruların aydınlatılmaya ihtiyacı vardır.

$\mathrm{Bu}$ çalışma müşteriler ile yoğun etkileşim içinde bulunulan gece ekonomisinin bir parçası olan bar çalışanlarının deneyimlerine 1şı tutmayı amaçlamıştır. Kadınlar için tehlikeli addedilen mekânlarda çalışırken cinsel tacize karşı geliştirilen stratejilerin ataerkil yapıyı nasıl yeniden inşa ettiği bulgular ışığında analiz edilmeye çalışılmıştır. Gece ekonomisi içinde yer alan kadın barmenlerin ve diğer alanlarda çalışan kadınların emek sürecindeki farklı deneyimlerini anlamak, açıklamak ve tartışabilmek için bu bağlamda yürütülecek yeni araştırmalara ihtiyaç olduğu açıktır.

\section{Yazarın Notu}

Bu çalışmada ikinci yazarın bitirme tezi kapsamında topladığı verilerin bir kısmı kullanılmıştır. Zaman ayırarak bu çalışmayı okuyan ve değerli katkılar sunan Yelda Özen, Asiye Kemik, Çağlar Özbek ve Serhat Kürklü’ye teşekkür ederiz. 


\section{KAYNAKÇA}

Acker J. (1990). "Hierarchies, Jobs, Bodies: A Theory of Gendered Organizations”. Gender and Society 4/2 (1990) 139-158.

Adkins L. (1995). Gendered Work: Sexuality, Family and the Labour Market. Buckingham 1995.

Anderson T., Daly K. \& Rapp L. (2009). "Clubbing Masculinities and Crime: A Qualitative Study of Philadephia Nigthclub Scenes”. Feminist Criminology 4/4 (2009) 302-332.

Aydemir M. \& Alıcilar A. (2009). "The Relationship Between Ethical Climate and Sexual Harrasment: An Emprical Study with Nurses”. İş Ahlakı Dergisi 2/3 (2009) 75-95.

Bayram G. O. \& Dinç H. (2012). "Sexual Harrasment among Health Workers and Students”. International Journal of Human Sciences 9/1 (2012) 20-34.

Beck U. (2000). The Brave New World of Work. Çev. P. Camillar. Cambridge 2000.

Bolton S. C. (2004). Emotion Management in the Work Place. New York 2004.

Bruner L. K. \& Dever M. (2014) "Work, Bodies and Boundries: Talking Sexual Harrasment in the New Economy”. Gender, Work ad Organization 21/5 (2014) 459-471.

Çelik Y. \& Çelik S. Ş. (2007). "Sexual Harrasmnet Against Nurses in Turkey". Journal of Nursing Scholarship 39/2 (2007) 200-206.

Coffey J., Farrugia D., Adkins L. \& Threadgold S. (2018). "Gender, Sexuality, and Risk in the Practice of Affective Labour for Young Women in Bar Work”. Sociological Research Online (2018) 1-16.

Creighton H. (1982). "Tied by Double Apron Strings: Female Work Culture and Organization in a Resturant”. Insurgent Sociologist 11 (1982) 59-64

Erdemir F., Çıtak E. A., Ulusoy H. \& Geçkıl E. (2011). "Hemşilerin Hastalar Tarafından Cinsel Tacize Uğrama Durumlarının Belirlenmesi”. Sağllk Bilimleri Fakültesi Hemşirelik Dergisi (2011) 27-35.

Eurofound (2017). $6^{\text {th }}$ European Working Conditions Survey-Overview Report (2017 Update). Publications Office of the European Union, Luxembourg 2017. Kaynak: <https://www.eurofound. europa.eu/surveys/european-working-conditions-surveys/sixth-european-working-conditions-survey2015>.

Gerni M. (2001). “İşyerinde Cinsel Taciz: Erzurum İlinde Bankacılık Sektörü Üzerine Bir Uygulama, Ankara Üniversitesi”. SBF Dergisi 56/3 (2001) 19-46.

Good L. \& Cooper R. (2016). “'But It's Your Job to Be Friendly': Employess Coping with and Contesting Sexual Harassment from Customers in the Service Sector". Gender, Work and Organization 23/4 (2016) 447-469.

Griffing C., Szmigin I., Bengry-Howell A., Hackley C \& Mistral W. (2012). "Inhabiting the Contradictions: Hypersexual Feminity and the Culture of Intoxication among Young Women in UK". Feminism \& Psychology 23/2 (2012) 184-206.

Guerrier Y. \& Adib A. S. (2000). “'No, We Don’t Provide That Service’: The Harassment of Hotel Employees by Customers”. Work, Employment and Society 14/4 (2000) 689-705.

Guiffre P. \& Williams C. L.(1994). "Boundary Lines: Labelling Sexual Harrasment in Restaurants”. Gender and Society 8/3 (1994) 374-401.

Hall E. J. (1993). “Smiling, Deferring, and Flirting Doing Gender by Giving ‘Good Service’”. Work and Occupations (1993) 20 452-471.

Hochschild A. R. (1983). The Managed Heart: Commercialization of Human Feelings. Berkeley 1983.

Hubbard P. (2007). “The Geographies of 'Going Out': Emotion and Embodiment in the Evening Economy”. Eds. J. Davidson, L. Bondi \& M. Smith, Emotional Geographies (2007)117-134. Aldershot.

Huebner L. C. (2008). "It is Part of the Job: Waitress and Nurses Define Sexual Harassment". Sociological Viewpoins (Fall 2008) 75-90.

Kavanaugh P. R. \& Anderson T. L. (2009). "Managing Physical and Sexual Assault Risk in Urban Nightlife: Individual and Environmental Level Influences”. Deviant Behavior 30/8 (2009) 680-714

Kavanaugh P. R. (2013). “The Continuum of Sexual Violence: Women's Accounts of Victimization in 
Urban Nightlife”. Feminist Criminology 8/1 (2013) 20-39.

Kisa A. \& Dziegielewski S. F. (1996). "Sexual Harrasment of Female Nurses in a Hospital in Turkey”. Health Services Management Research 9 (1996) 243-253.

Kısa A., Dziegielewski S. F. \& Ateş M. (2002).”Sexual Harasment and Its Consequences: A Study within Turkish Hospitals”. Journal of Health \& Social Policy 15/1(2002):77-94.

Knights D. \& Thamen T. (2005). “Embodying Emotional Labour”. Eds. B. Brandth, E. Kvande \& D. Morgan, Gender, Bodies and Work (2005) 31-41. Aldershot.

Leyshon M. (2008). “'We're Stuck in the Corner’: Young Women Embodiment and Drinking in the Counrtryside”. Drugs: Education, Prevention and Policy 15/3 (2008) 267-289.

MacKinnon C.A. (1979). The Sexual Harrasment of Working Women: A Case of Sex Discrimination. New Haven 1979.

Mears A. (2014). “Aesthetic Labor for the Sociologies of Work, Gender and Beauty”. Sociology Compass 8/12 (2014) 1330-1343.

Mellgren C., Andersson, M. \& Ivert A. K. (2017). “'It Happens All the Time’: Women’s Experiences and Normalization of Sexual Harrassment in Public Space”. Women and Criminal Justice (2017) 120. Kaynak: <https://doi.org/10.1080/08974454.2017.1372328>.

Mishler E.G. (1986). Research Interviewing: Context and Narrative. Cambridge 1986.

Muñoz C. L., Wood N. T. \& Solomon M. R. (2006). "Real or Blarney? A Cross-cultural Investigation of the Perceived Authenticity of Irish Pubs” Journal of Consumer Behaviour 5/3 (2006) 222-34

Neuman W. L. (2013). Toplumsal Araştırma Yöntemleri Nitel ve Nicel Yaklaşımlar. Çev. S. Özge. Ankara $2013^{6}$.

Nicholls E. (2017). “'Dulling It Down a Bit’: Managing Visibility, Sexualities and Risk in the Night Time Economy in Newcastle, UK”. Gender, Place and Culture 24 /2 (2017) 260-273.

Riach K. \& Wilson F. (2014). "Bodyspace at the Pub: Sexual Orientations and Organizational Space”. Organization 21/3 (2014) 329-345.

Spradley J. P. \& Mann B. J. (1975). The Cocktail Waitress Women’s Work in a Man's World. New York 1975.

Standing G. (2014). Prekarya: Yeni Tehlikeli Sınıf. Çev. E. Bulut. İstanbul 2014.

Şahin M., Aydın B. \& Sarı S. V. (2012). “Avm’lerde Çalışan Kadın Satış Danışmanlarının Cinsel Tacize İlişkin Görüşleri”. Cumhuriyet International Journal of Education 1/2 (2012) 67-81.

Taylor S. (1997) “'Empowerment’ or ‘degradation’? Total Quality Management and the Service Sector”. Ed. R. K. Brown, The Changing Shape of Work (1997) 171-202. New York.

Toker Y. (2016). "İşyerlerinde Cinsel Taciz: Kapsamı, Öncülleri, Sonuçları, Kurumsal Baş Etme Yöntemleri”. Türk Psikoloji Yazıları 19/38 (2016) 1-19.

Ulusoy H., Swigart V. \& Erdemir F. (2011). "Think Globally, Act locally: Understanding Sexual Harassment from a Cross-Cultural Perspective”. Medical Education 45 (2011) 603-612.

Unur K. \& Şanlı S. C. (2018). “Staj Yapan Öğrencilere Yönelik Cinsel Taciz: Otel İşletmeleri Örneği”. Seyahat ve Otel Issletmeciliği Dergisi 15/1 (2018) 189-161.

Waitt G., Jessop L. \& Gorman-Murray A. (2011). "The Guys in There just Expect to be laid: Embodied and Gendered Social-Spatial Practices of a 'Night out' in Wollongong, Australia”. Gender, Place and Culture. A Journal of Feminist Geography 18 (2011) 255-275.

Warhurst C. \& Nickson D. (2009). “'Who’s Got the Look?’ Emotional, Aesthetic and Sexualized Labour in Interactive Services”. Gender, Work and Organization 16/3 (2009) 386-404.

Wolkowitz C. (2006). Bodies at Work. London 2006. 